\title{
Transformation of the Landscape in the Conditions of the Slovak Republic for Tourism
}

\author{
Daša Oremusová, Magdaléna Nemčíková *(i) and Alfred Krogmann
}

Department of Geography and Regional Development, Faculty of Natural Sciences, Constantine the Philosopher University in Nitra, Tr. A. Hlinku 1, 94901 Nitra, Slovakia; doremusova@ukf.sk (D.O.); akrogmann@ukf.sk (A.K.)

* Correspondence: mnemcikova@ukf.sk

check for updates

Citation: Oremusová, D.;

Nemčíková, M.; Krogmann, A.

Transformation of the Landscape in the Conditions of the Slovak Republic for Tourism. Land 2021, 10, 464 https://doi.org/10.3390/land 10050464

Academic Editor: Theano S. Terkenli

Received: 24 March 2021

Accepted: 25 April 2021

Published: 29 April 2021

Publisher's Note: MDPI stays neutral with regard to jurisdictional claims in published maps and institutional affiliations.

Copyright: (c) 2021 by the authors. Licensee MDPI, Basel, Switzerland. This article is an open access article distributed under the terms and conditions of the Creative Commons Attribution (CC BY) license (https:// creativecommons.org/licenses/by/ $4.0 /)$.

\begin{abstract}
Tourism is one of the most dynamic sectors of the economy in Slovakia. With the orientation of localities to tourism, the landscape transformation is reflected in several positive and negative changes in the landscape. The aim of the contribution is to highlight the transformation processes leading to the creation of a tourist landscape in six selected localities in Slovakia. When selecting sites, we applied criteria such as the diversity of the original use, size or attractiveness. The environmental, socio-cultural and economic impacts of tourism on the landscape of localities were valuable in terms of sustainable development principles. From the methodological point of view, the primary methodology was the drivers-pressures-state-impact-response (DPSIR) model, used for integrated environmental assessment and the life cycle methodology of a tourism center with integrated sustainable development indicators. In the work results, based on the analysis of the historical development and the current state of localities, we evaluate their phase of the life cycle and the effects of tourism on the environment. We also present the possibilities of further development and heading direction of localities from point of view of tourism while pointing out the benefits and risks connected with the planned development.
\end{abstract}

Keywords: landscape transformation; tourist landscape; impacts of tourism on the landscape; sustainable tourism; Slovakia

\section{Introduction}

The landscape is the capital for tourism. In a country with attractiveness that can result from natural factors and is the result of people and their activities, tourism primarily develops. Secondarily, tourism can also grow in places that have been used primarily for other purposes in the past. Examples are transforming a mining landscape [1] or an industrial landscape [2,3] into a tourist landscape. The result of primary and secondary activities of tourism is the transformation of the original types of the landscape into a tourist landscape. We perceive a tourist landscape according to Gunn [4] as the total physical and visual environment utilized by all tourism activities, including the whole context and infrastructure of tourism development, such as transportation, services, information, direction and, generally speaking, all such developments that attract people to a destination. Increasingly, the use of the tourist type of landscape is characterized as insensitive in terms of natural components [5-7], as well as the local population [8-10].

We, therefore, consider it very important to know the impact of tourism on the landscape, even in areas that have begun to develop tourism relatively recently and embarked on the transformation process into a tourist landscape, and the possible contribution to the sustainable development of partial areas. In this context, we raise a research question: How is the transformation of the country into a recreational landscape in selected locations which have not been used primarily for tourism, and to what extent, in line with the requirements of sustainable development?

The aim of the contribution is to highlight the transformation processes leading to the creation of a tourist landscape in six selected localities in Slovakia. As criteria of selection, 
we chose the diversity of the original use, size and attractiveness. The evaluation included the environmental, socio-cultural and economic impacts of tourism on the landscape of localities in terms of the principles of sustainable development. From a methodological point of view, the primary methodology was DPSIR, which illustrates the cause and effect relationship between environmental and human systems.

We subsequently documented the impact of tourism on representative destinations through a modified life cycle model, reflecting the criterion of such currently important sustainability. Additionally, in the paper, we present scenarios of further development and direction of localities considering tourism. In parallel, we will highlight the benefits but also the risks associated with the planned development.

\section{Theoretical Background}

Every landscape, including the tourist landscape, is original. Its changes can be evaluated according to Žigrai [11] based on the most important universal quantities of space and time. Space and time create an environment in which natural and human forces form and permanently transform a natural landscape into a cultural one and form its unique character [12]. Many new elements and structures are superimposed upon the traditional landscapes during the transformation that become highly fragmented and lose their identity [13]. Changes to the landscape are of interest to several geographical and landscape-ecological studies. The concept of driving forces of landscape changes is has been addressed in several studies. Bürgi, Hersperger and Schneeberger [14] identified that the spatial, temporal and institutional scales determine the driving forces of landscape change. Hersperger et al. [15] present four basic models for linking land change with driving forces and actors. The proposal of alternative pathways of some of the major myths of driving forces of land cover change is the aim of the article of Lambin et al. [16]. The analysis of changes in the landscape is important in terms of understanding the dynamics of its development, not only in the past but also in the future [17]. A detailed overview of the research and mapping of land use in the context of Slovakia is provided in the work of the authors Ot'ahel' and Feranec [18]. According to Burley [19], land use stems from knowledge of the land cover and its function.

From the point of view of understanding this issue in wider territorial relations, the contribution of Prokopová et al. [20] can be inspiring, where the authors analyze transformation processes in Eastern Europe, including Slovakia. The driving forces of landscape change across Europe are presented by Plieninger et al. [21] with a systematic synthesis of 144 case studies. In a European and global context, it is necessary to mention, in terms of research into landscape changes, the implementation of various projects or programs that not only serve as suitable data sources, but also integrate the latest scientific knowledge or methodologies in this area. The most famous are the Global Land Programme (GLP) [22], which succeeds land use and land cover change (LUCC) and the Copernicus Land Monitoring Service (CLMS) [23], which provides information on land cover and land use and their change in Europe.

If the cultural landscape is used for recreational purposes according to the landscape's predominant type of activity, we indicate its subtype-the tourist landscape. Definitions of the tourist landscape can be found in a few interesting publications. Skowronek et al. [24] (p. 81) "identify tourist landscape as an area, peculiar in its physiognomy and structure, differing from other landscape types. It is recognizable and accepted by its users, created to meet their touristic and recreational needs and expectations." Terkenli [25] (pp. 185-186) claims that due especially to its experiential character, the landscape becomes a social interface where local and global perspectives and other dimensions of tourism studies come together in the ready construction and consumption of place identity. In the article of Gkoltsiou and Terkenli [26] is presented a methodological framework for assessing the structure of tourist landscapes. It is based on elements and aspects of both tourism and landscape, comprising the tourist landscape, and on qualitative and quantitative methods of landscape analysis. A detailed systematic overview of the papers dated 2003-2013 
focused on the research of the mutual interaction of tourism and Skowronek et al.'s [24] process landscape. In Landscape, Tourism and Meaning, the authors [27] also deal with a landscape approach to tourism theory.

In connection with assessing the impacts of tourism on the environment, the authors Hall and Page in The Geography of Tourism and Recreation [28] deal mainly with environmental, socio-cultural and economic impacts. At present, the topic of sustainable development is also present in the works on tourism. As early as 1997, the authors Wahab and Pigram [29] in the book "Tourism, Development and Growth: The Challenge of Sustainability" deal with sustainability and opportunities and challenges in sustainable tourism. Zelenka [30] deals with research into the sustainability of tourism in the destination as well as the presentation of appropriate methods. Environmental aspects of tourism represent the key focus of the study "Environmental Studies in Tourism" from Pásková [31]. The works of Szromek [32] and Szromek et al. [33] show a combination of several approaches to identification of the life cycle stage of a tourism destination in the context of the implementation of sustainable development practices in tourism.

\section{Materials and Methods}

When selecting six tourist sites (Alekšince, Čierny Balog, Butkov, Hniezdne, Špania dolina, Podhájska) (Figure 1), several criteria were decisive ones. The first criterion was the transformation of the landscape. Localities were selected where the origin of the tourist landscape was a secondary phenomenon. The second criterion in the selection was the diversity of its original use. The third criterion was the size and attractiveness of the site. Through gradual selection, we identified six localities that are not considered to be attractive as a first impression and certainly are not the top destinations in Slovakia, but have recreational potential at different qualitative levels (diversity of localization, implementation and selective assumptions [34]). These localities are in regions where the intensity of tourism is not high [35].

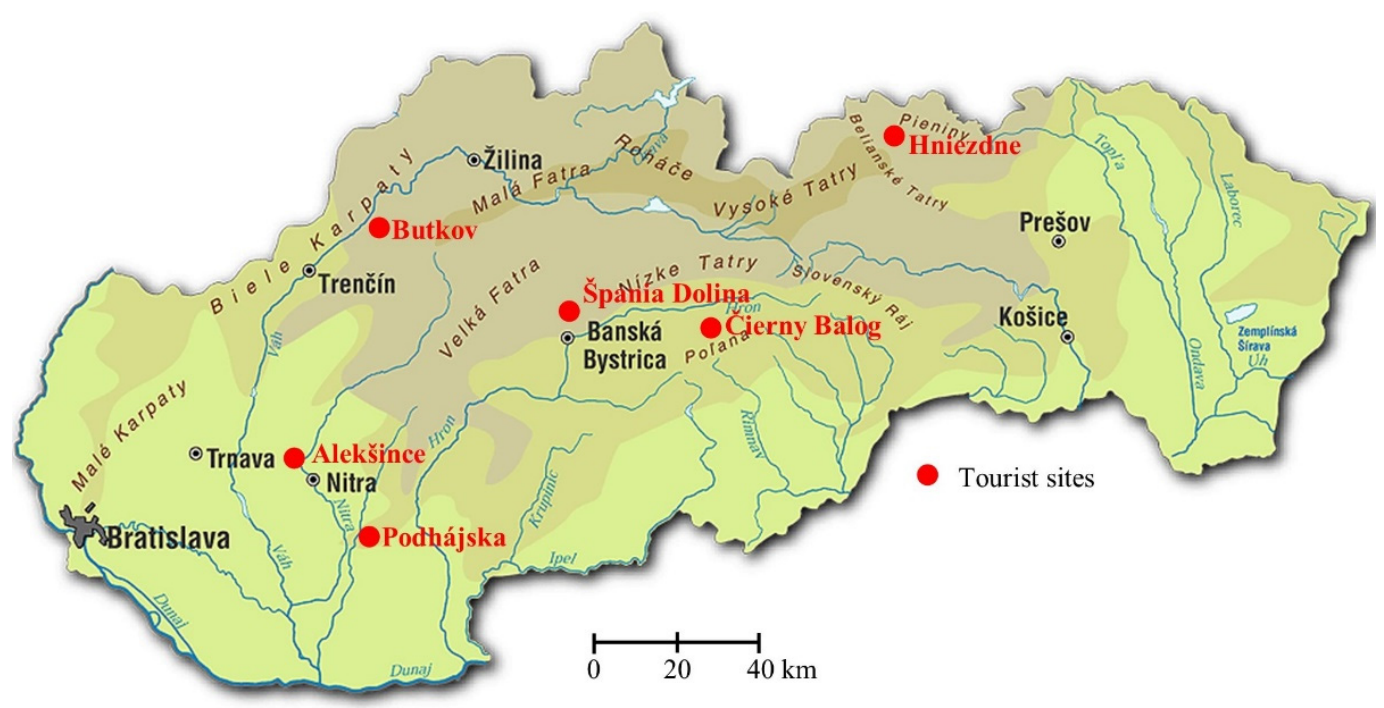

Figure 1. Selected tourist sites and their localization in Slovakia. Source: Adapted with permission from ref. [36]. Copyright 2005-2021 e-Slovensko.cz.

The source of information during the field research, in addition to text documents, were map sources as well as aerial photographs. The black and white images with a resolution of $0.5 \mathrm{~m}$ come from the 1940s and 1950s [37]. We used a color orthophotomosaic to display and interpret the current state of the landscape. The orthophotomosaic was created in the years 2017-2019 based on the processing of aerial laser scanning data. Its final positioning accuracy is $0.3 \mathrm{~m}$ [38]. Several print and electronic resources were used for the characteristics of sites. Development and strategic documents were important in 
connection with their development, such as economic development and social development programs, zoning plans, etc.

To reach the paper's primary goal, it was necessary to apply several methods to assess the impact of tourism on the landscape. We first evaluated the sites using the causal framework, also known as DPSIR. It is a methodological tool of integrated environment assessment (IEA). The model's name is an abbreviation of the first letters of driving force, pressure, state, impact and response. It was developed by the European Environment Agency, which added driving force and impact to the pressure-state-response (PSR) model developed by the OECD [39]. Driving forces, which are the triggering mechanisms of processes in society, cause pressure on the environment. Pressure (positive and negative) is the immediate cause of changes in the state of the environment. The impact is logically followed by response, in which measures and tools are formulated to eliminate or remediate environmental damage [40]. The DPSIR model can also be applied in assessing the impact of tourism on the landscape or the destination. As part of the integration of environmental policy, sets of aggregated and individual indicators were compiled for the conditions of Slovakia for six sectors of economic activity, including tourism. For tourism needs, 8 aggregated indicators and 30 individual indicators were set, which are continuously updated [41]. We applied this methodology aligned with the method of Pásková [31] and, in addition to environmental impacts, we also assessed the socio-cultural and economic impacts of tourism on a specific locality. In addition, we evaluated the adverse effects of these influences, but we also emphasized their positive impact (Figure 2).

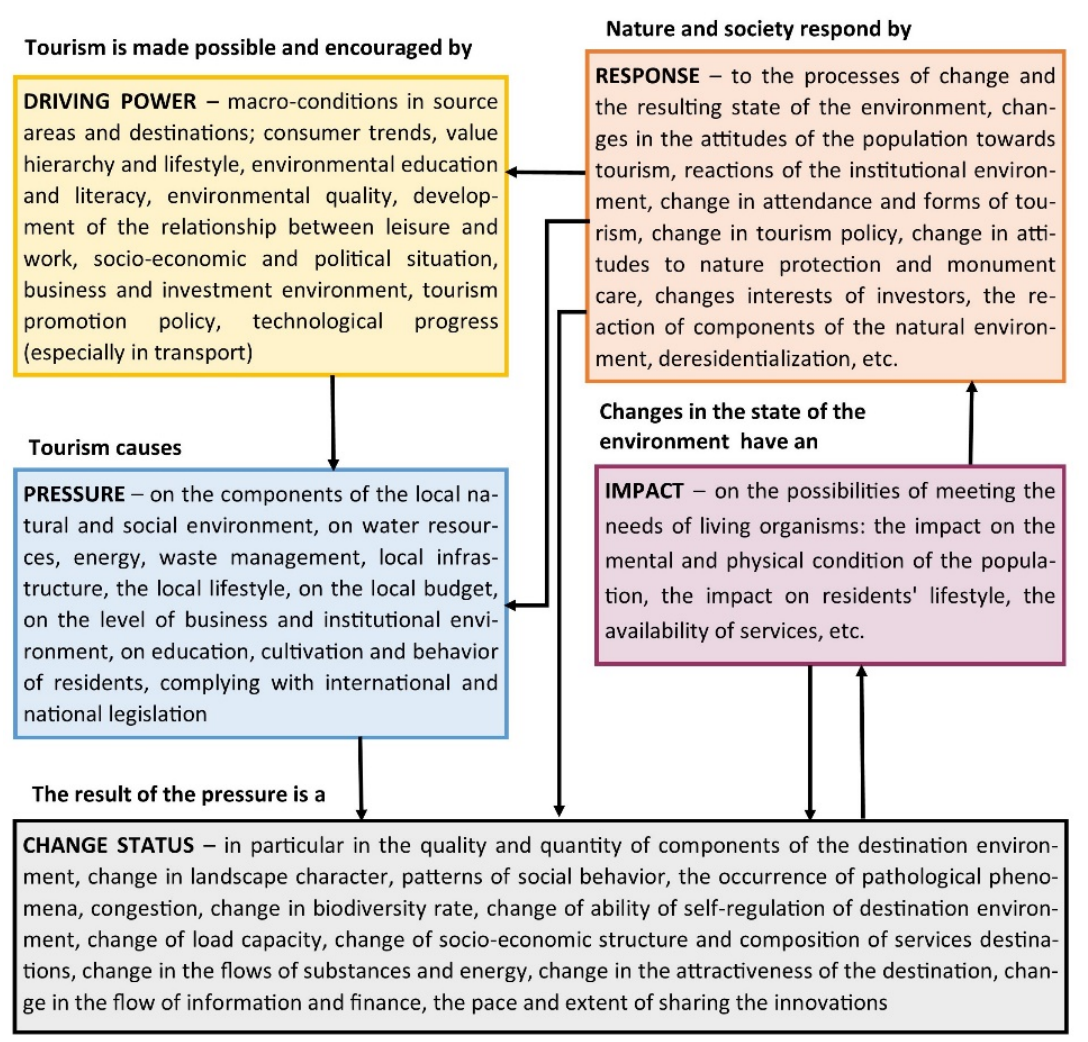

Figure 2. DPSIR model for tourism. Source [31].

The well-used Butler's model of the destination life cycle is one of the most well-known tourism center evaluations [42]. According to Pásková [31], the destination model's dynamic nature is interesting for geographers dealing with tourism development in specific localities. The model makes it possible to consider the spatial-temporal aspect and the impact on individual components of the recreational landscape. The model goes through constant development and various modifications, as evidenced by Butler and other authors [43]. In this paper, we are inspired by a modified model (Figure 3) by Szromek et al. [33]. 


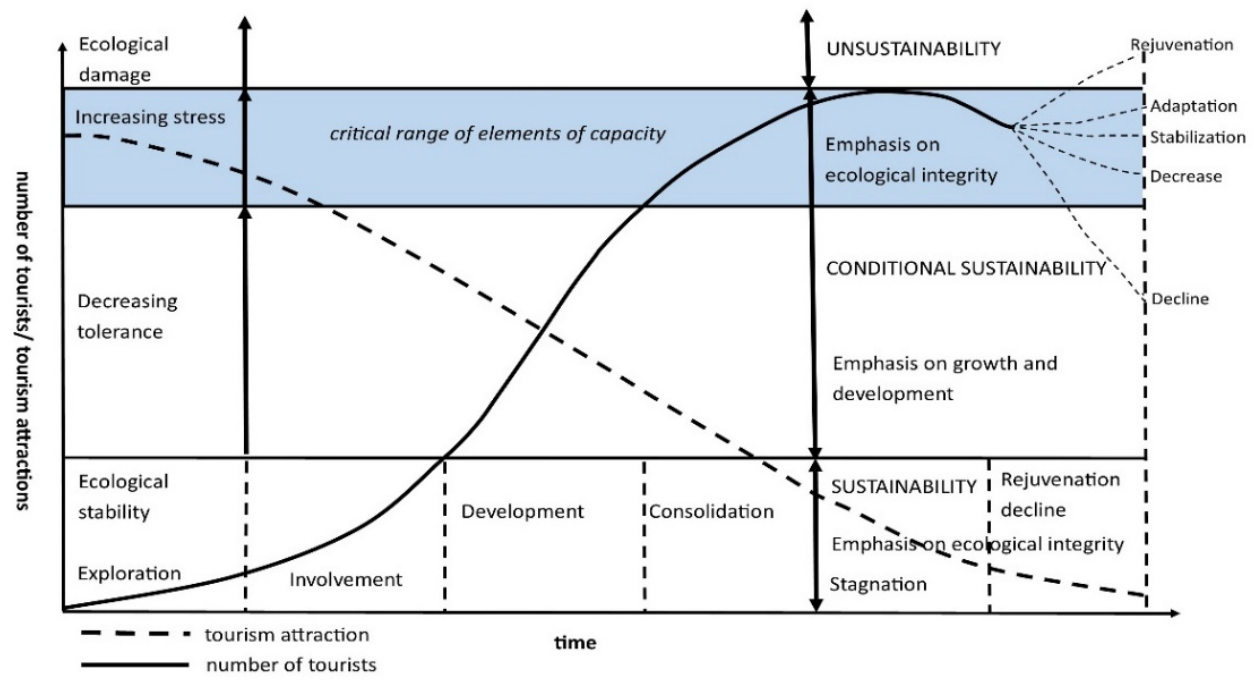

Figure 3. Life cycle model of a recreation center concerning sustainable development. Source [33,42].

The model describes the spatial and other changes that the tourism center is experiencing in its development. Based on increases of incoming tourism and the growth of the number of infrastructure facilities, various stages of development of the center can be identified from the initial level to the peak [44]. At the same time, the model also reflects the impact of an increasing number of visitors on the ecological stability of the territory as well as its sustainable development. There are 6 phases of the life cycle of the tourist center. The first phase is referred to as exploration and represents the process of discovering and creating the tourist site. It is characterized by minimal tourist traffic. The sustainable development of the territory is typical, which is based on functioning natural processes in the territory without significant anthropogenic interventions. The second phase represents penetration of tourism into the site. There is minimal impact on local society, and the landscape and its environment remains. Sustainable development with minimal manifestations of risk factors, and with few anthropogenic environmental interventions, is still prevalent in the landscape. Due to the increasing number of visitors in connection with seasonality, there may gradually be more pressure on the landscape. The third phase is the development of the tourism site. It is accompanied by the conversion of native natural landscape types and original sites into sites with a dominant recreational function. The development phase has a major impact on the environment and the local economy. The landscape is moving from a state of sustainable development to a state of conditional sustainability. In such a case, the sustainability of the territory needs to be targeted at the construction of a tourism center. It is essential to determine in advance the restrictions and limits of intervention in the territory. At this stage, the anthropogenic pressure on declining ecosystem tolerance is reflected in the growing stress in the landscape and in the decreasing ecological stability of the territory. The fourth phase is consolidation. The number of tourists already exceeds the number of locals and continues to grow. A distinct central tourist zone is being formed in the landscape and ecological damage reaches its highest levels. Stress persists in the landscape until it grows. The territory's tolerance for change is very low, as the territory has undergone significant and often irreversible changes. The fifth phase is the stagnation of the tourism center. It is associated with a conflict between the level and intensity of tourism and the recreational potential or carrying capacity of the landscape. In addition to the negative consequences for the natural components of the landscape, negative impacts on the social and cultural environment are also felt. Environmental damage reaches the peak in the landscape, and the landscape significantly changes its appearance, structure and function. Alternatively, the tourism center may move from stagnation to rejuvenation, adaptation, stabilization, decrease or decline $[42,45,46]$. 


\section{Results \\ 4.1. Examples of Transformed Territories of Slovakia into Tourism Localities 4.1.1. Alekšince}

An example of a transformed landscape with the military form of relief is the village of Alekšince, specifically its Museum of Socialism and the Cold War. The village of Alekšince is located in the west of Slovakia. The area of the village is $15.07 \mathrm{~km}^{2}$ and the village has 1669 inhabitants (as of 31 December 2019). The relief of lowland hills is dominant, while the village center is located at an altitude of $162 \mathrm{~m}$. The traditional landscape type of the municipality in terms of land use is agricultural landscape, which accounts for $89.9 \%$. Arable land takes up $82.4 \%$ of the village area, vineyards $3.23 \%$, gardens $2.67 \%$ and permanent grassland $1.48 \%$. Built-up areas dominate the non-agricultural land with $7.3 \%$ of the municipality's area. Forests have only a minimal share of $0.4 \%$ of the current landscape structure. Water areas represent only $1.8 \%$. Thus, agriculture still has an important position in the economy of the municipality. Crop production carried out by several agriculture companies and privately farmed land prevails, and animal production, focused on horse breeding, is also represented.

The Museum of Socialism and the Cold War was established in the village in a former underground military shelter in 2012 (Figure 4).

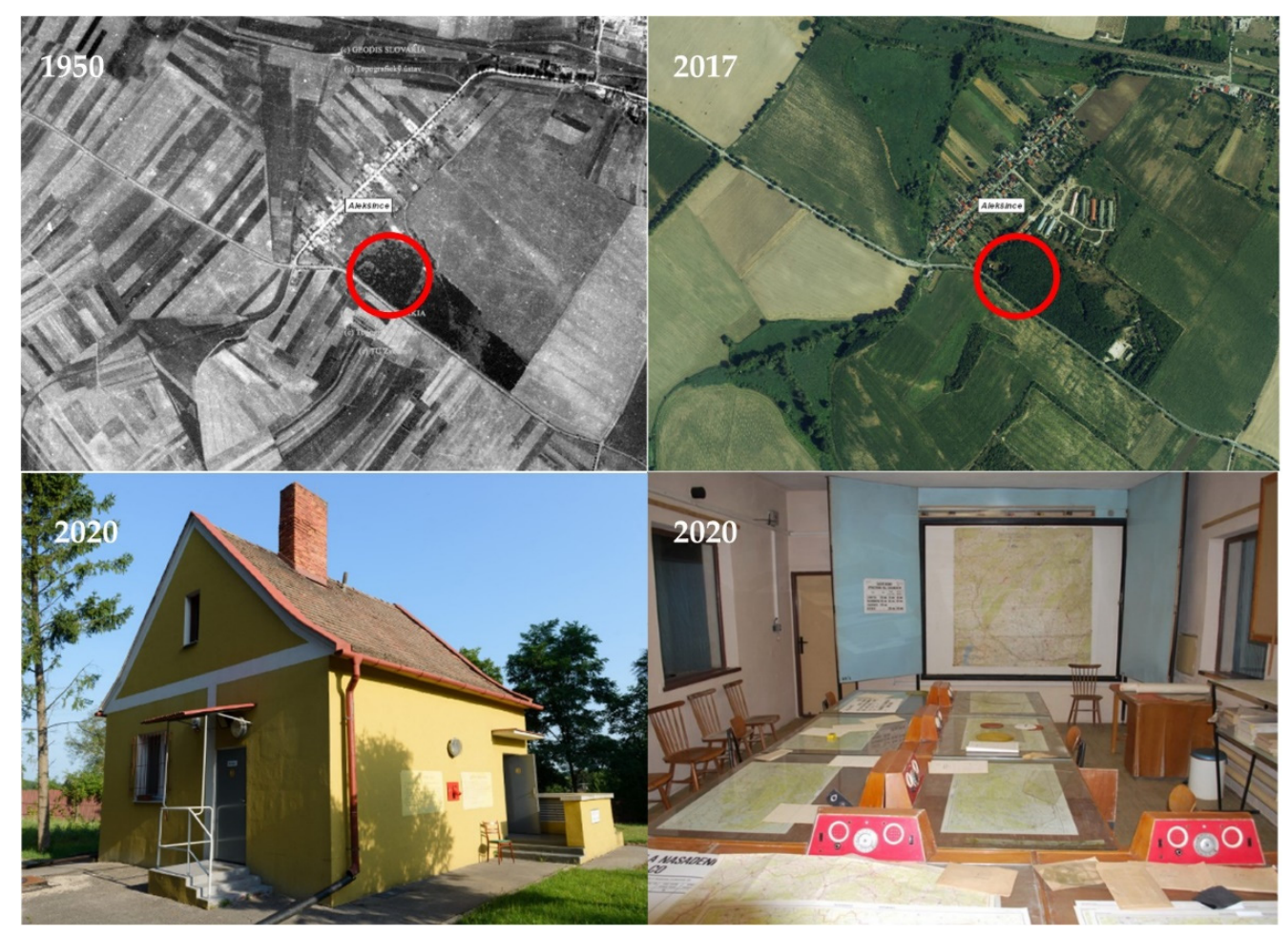

Figure 4. Visual interpretation of the Alekšince (Museum of Socialism and the Cold War) site. Source: 1950-Adapted with permission from ref. [37]. Copyright 2021 GEODIS SLOVAKIA, s.r.o. Bratislava, Topografický ústav Banská Bystrica. 2017-Adapted with permission from ref. [38]. Copyright 2021 GKÚ Bratislava, NLC Zvolen. 2020 left-Reprinted with permission from ref. [47]. Copyright 2021 Dromedar.sk. 2020 right-Reprinted with permission from ref. [48]. Copyright 2019 Miribord.

It is unique in Slovakia, as the museum is located at a depth of $7 \mathrm{~m}$ underground. The military underground shelter against weapons of mass destruction was built in the 1960s [47]. The shelter consists of a massive monolithic reinforced concrete skeleton with a tangle of corridors and rooms with an area of $350 \mathrm{~m}^{2}$. The specialized museum maps the period of Slovak military history in the period 1948-1989. The museum has two basic parts-exterior and interior. The exterior includes statues from socialism, which stood at the squares of Slovak towns and villages and military equipment from the Cold War. In 
the interior, the first section presents the underground shelter equipment from the Cold War and the second section presents the Cold War's atmosphere and character through exhibits, information panels and audiovisual recordings $[48,49]$. The position and area dimensions of the site in which the Museum of Socialism and the Cold War is located in the rated periods of 1950 and 2017 do not show further changes that are significant. The 1950 orthophotoimage is a small shot of a location on the land whose surroundings comprise forests and arable land. Due to the type of construction and the period, it is easily identifiable. The 2017 orthofotomosaic is the same. The immediate surroundings are still forests and agricultural land. Significant interventions in the land in the form of technical or social infrastructure are not evident in connection with the museum. Based on the obtained statistical data and reconnaissance of the terrain, we compiled a DPSIR model (Table 1).

Table 1. DPSIR model for Alekšince.

\begin{tabular}{|c|c|}
\hline Component & Interpretation \\
\hline $\mathrm{D}$ (driving & $\begin{array}{l}\text { the potential identified by the civic association in the underground military shelter, the effective use of the } \\
\text { site, the follow-up to historical events in Slovakia, the development of the village, the revitalization of the } \\
\text { area that would otherwise be unused, public interest, overall tourism development }\end{array}$ \\
\hline $\mathrm{P}$ (pressure) & data increase in waste production, increased transport in the village, land use \\
\hline S (state) & data minimal air pollution, a change in the way the site is used, which is not just an environmental burden \\
\hline I (impact) & data operating and modification costs, new jobs, site modification and completion \\
\hline $\mathrm{R}$ (response) & $\begin{array}{l}\text { contribution to municipal taxes from tourist visits, completion of tourism products, non-traditional forms of } \\
\text { tourism, orientation towards cognitive tourism, support of the locality's educational significance, } \\
\text { construction of new attractions using military themes (combat attractions, survival courses, etc.) }\end{array}$ \\
\hline
\end{tabular}

Source: Own preparation.

The pros of the area are the offer of a retro tourist attraction, symbolized by the Museum of Socialism and the Cold War, but this museum is also important in education. The museum building does not represent an environmental burden. The absence of tourist infrastructure in the village can be identified as a con. Chance or the opportunity for sustainability is found in the anticipated networking of tourist sites with a similar focus. We consider the financial aspect, which will not allow the expansion of trendy multimedia presentations or virtual reality, to be the most problematic aspect. If the building is not further restored, it will remain abandoned and become a burden eventually.

\subsubsection{Butkov}

The Butkov locality is an example of the transformation of the landscape created by opencast mining. Butkov Hill (765 $\mathrm{m}$ above sea level) is located in northwestern Slovakia and limestone and silt have been mined on its northwestern slope for 132 years. By quarrying within the framework of visual-spatial significance, we rank it among the exposed dominant forms of anthropogenic relief of the Považie region, significantly changing the landscape's character [50]. It is a wall-type quarry, which currently has fifteen floors. Until 2012, this mining work did not differ from others in Slovakia. From 2012, a unique transformation of anthropogenic relief began on the southern side of the quarry, on its 11th floor, and mining is an ongoing process in the rest of the quarry [51] (Figure 5). On this floor of the quarry is the youngest pilgrimage site in Slovakia- " Rock Sanctuary of Divine Mercy on Butkov", which is gradually transforming into a center of religious tourism. The complex of the rock sanctuary consists of several sacral buildings. In 2013, the first $12 \mathrm{~m}$ cross was built, then the monument of St. John Paul II (2014), the memorial of St. Sister Faustina (2015), Chapel of the Divine Mercy (2016) and $900 \mathrm{~m}$ long stone Stations of the Cross (2016) [52]. In May 2017, another significant landmark was added to the complex, a $6 \mathrm{~m}$ high statue of the Virgin Mary, the Mother of Mercy, which measures $9 \mathrm{~m}$ with the pedestal, making it the tallest statue of the Virgin Mary in Central Europe 
(Figure 5). The complex also includes a stage and an auditorium where either services or concerts take place. Regular pilgrimages take place twice a year. During the construction of the entire complex, including the sacral buildings, the quarry's material was used as much as possible. The area also includes additional services such as stalls with devotionals, refreshments and sanitary facilities. The whole complex is electrified and a potential visitor can view a substantial part of it through not only the website but also by broadcasts via a live camera [53]. The attractiveness of the locality is increased by the possibility of beautiful views of the Považie region as well as the Biele Karpaty Mountains.

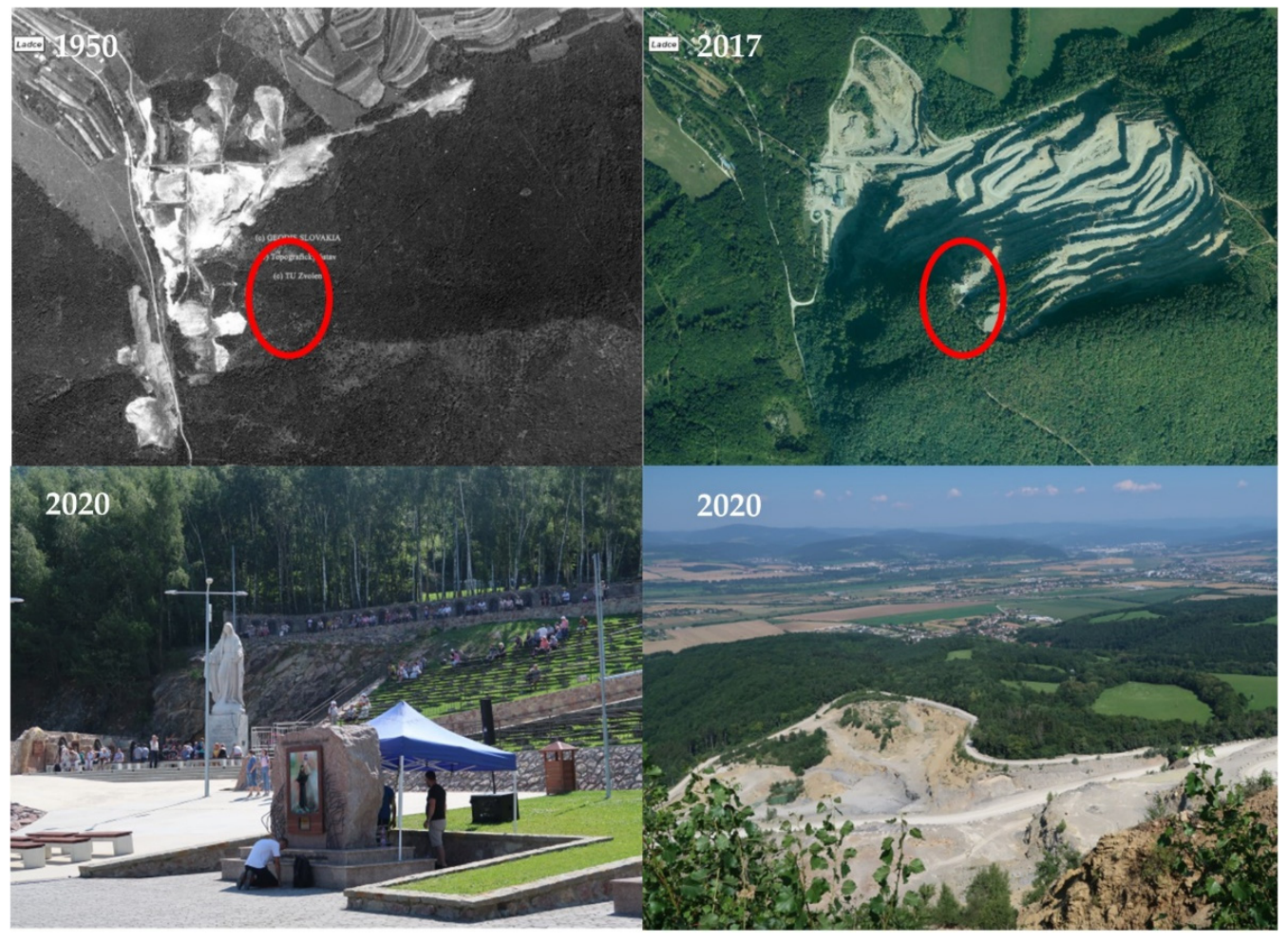

Figure 5. Visual interpretation of the Butkov (The Rock Sanctuary of Divine Mercy on Butkov) site. Source: 1950-Adapted with permission from ref. [37]. Copyright 2021 GEODIS SLOVAKIA, s.r.o. Bratislava, Topografický ústav Banská Bystrica. 2017-Adapted with permission from ref. [38]. Copyright 2021 GKÚ Bratislava, NLC Zvolen. 2020—author's photo.

The rock sanctuary is located in the cadaster of the village of Ladce. The area of the village is $15.69 \mathrm{~km}^{2}$ and the village has 2587 inhabitants (as of 31 December 2019). It is located about $5.6 \mathrm{~km}$ from the village. The landscape structure of the village is dominated by forests (34.87\%), and other areas, where mining areas and recreational areas are $8.38 \%$ of the total area [54]. Agricultural land makes up $42.39 \%$, while arable land has a share of $20.78 \%$. Gardens occupy $2.23 \%$, permanent grassland $19.28 \%$, water areas $4.28 \%$ and $10.05 \%$ of the municipality is built up.

The company Považská cementáreň, a.s. Ladce has long been the largest employer in the area and plays a significant role in the economic development in the region. A positive benefit of the company is the implementation of activities following sustainable development. The company also excels in its philanthropic activities, as evidenced by the Rock Sanctuary of Divine Mercy on Butkov, in the creation of which this company has the largest share and puts in the most effort.

In this locality, we can observe a very significant change in land use in the time horizon of 1950 to 2017. According to the historical orthophotomap from 1950, it is clear that the locality of today's sanctuary was wooded. Mining was realized at lower altitudes, west to northwest of current quarry. The orthophotomosaic from 2017 already captures the transformation of the mining landscape. On the 11th floor of the quarry, a complex has 
constantly been under construction since 2012, which is becoming an important center of religious tourism, based on the obtained statistical data and reconnaissance of the terrain (Table 2).

Table 2. DPSIR model for Butkov.

\begin{tabular}{cl}
\hline Component & \multicolumn{1}{c}{ Interpretation } \\
\hline D (driving force) & $\begin{array}{l}\text { construction of sacred buildings, public interest in religious and secular motifs, organization of events } \\
\text { (pilgrimages, concerts), convenient and transport accessibility, cooperation with the Sanctuary of Divine } \\
\text { Mercy in Krakow-Lagievniki, the involvement of the management of Považská cemenáren,, a.s. Ladce } \\
\text { and municipality government, trends in tourism that appeal to life attitudes to the search for new, } \\
\text { peaceful and spiritual aspects }\end{array}$ \\
\hline $\mathrm{P}$ (pressure) & $\begin{array}{l}\text { increasing the production of waste in the complex itself as well as in the parking lot, increasing the } \\
\text { built-up area of the complex, or parking areas }\end{array}$ \\
\hline $\mathrm{S}$ (state) & $\begin{array}{l}\text { the increased attractiveness of the locality, the village of Ladce and its surroundings, the completion of } \\
\text { the elements of the infrastructure of the area }\end{array}$ \\
\hline $\mathrm{I}$ (impact) & $\begin{array}{l}\text { costs of infrastructure construction, new jobs, increase in employment, impact on the lifestyle of the } \\
\text { residents of the village }\end{array}$ \\
\hline $\mathrm{R}$ (response) & $\begin{array}{l}\text { construction of other sacral buildings, construction of accommodation facilities, the cooperation of } \\
\text { several regional development subjects, completion of tourism products for domestic and travel agencies } \\
\text { from abroad (especially for Polish pilgrims worshipping St. Sister Faustina and St. John Paul II.) }\end{array}$ \\
\hline
\end{tabular}

Source: Own preparation.

The location excels with a strong story, which leads to the gradual transformation of a tourist-unattractive mining landscape with an anthropogenic form of relief into a religious landscape. In the context of the growing interest in the site in question, the con is the absence of accommodation. We also see an opportunity to develop the locality connected to the network of cultural routes such as St. Jacob's Way, where Butkov could be one of the stops. Such a transformed site will not represent an environmental burden, except for waste generation with long-term high traffic levels.

\subsubsection{Hniezdne}

Another example of a transformed landscape in which part of the tourist landscape is formed is the village of Hniezdne. The area of the village is $17.98 \mathrm{~km}^{2}$ and the village has 1445 inhabitants (as of 31 December 2019). In the territory there is a basin hill and the relief of plains and floodplains. The altitude in the middle of the village reaches $533 \mathrm{~m}$.

Historically, the area has undergone several changes. In the period of the 17th and 18th centuries, the settlement-craft landscape type was dominant. At the end of the 18th century, the village acquired an agricultural character. Since the 1990s, the industrial landscape type, represented by the industrial enterprise BGV, s.r.o. Hniezdne with a focus on the production of alcohol and alcoholic beverages, has been seen. Significant for the municipality's economy is the company BGV, s.r.o. Hniezdne [55], operating in the village for more than 20 years.

Since 2012, a tourist type of landscape began to be created in the village, primarily by $\mathrm{BGV}$, s.r.o. Hniezdne, which created a tourism operation in the eastern part of the village in the area of tourism known as Nestville Park. The basis for creating the park was establishing an exhibition of distilleries and traditional folk crafts-Nestville Distillery. Nestville Distillery consists of three parts-historical, modern and traditional. The historical part has examples of historical crafts related to distilling. The modern part presents one of the most modern refineries for alcohol production in Central Europe, with more than 35,000 tons of grain processed annually [56]. The traditional part consists of a tasting area and Nestville Whiskey maturing warehouses. The park also includes other parts such as Exposhop, Nestville Chocolate (Figure 6), a playground, Nestville Taberna (Figure 6), Nestville Horses, Nestville Apartments, Nestville Market and a skating rink. 

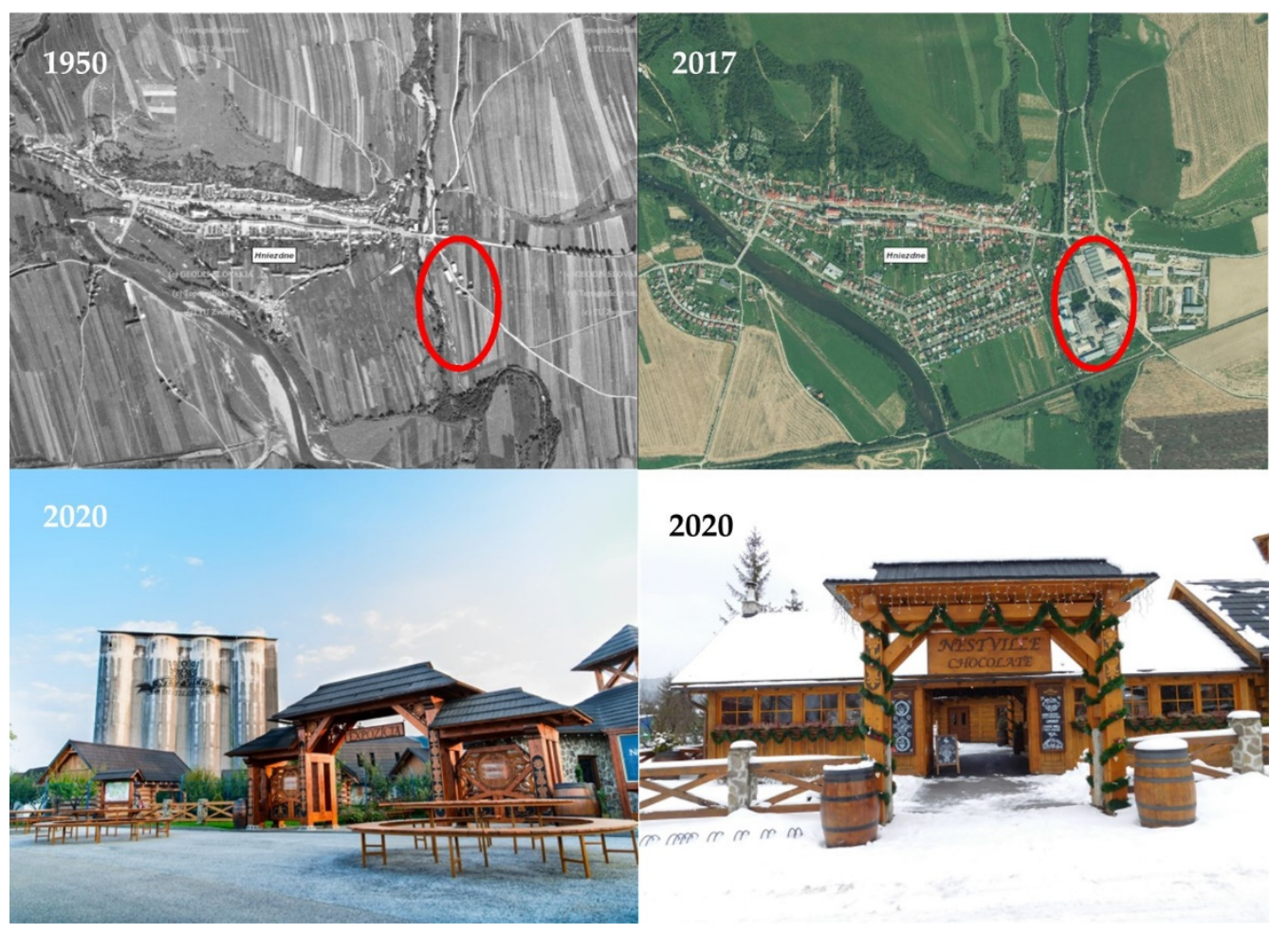

Figure 6. Visual interpretation of the Hniezdne site. Source: 1950-Adapted with permission from ref. [37]. Copyright 2021 GEODIS SLOVAKIA, s.r.o. Bratislava, Topografický ústav Banská Bystrica. 2017-Adapted with permission from ref. [38]. Copyright 2021 GKÚ Bratislava, NLC Zvolen. 2020 left-Adapted with permission from ref. [56]. Copyright 2020 BGV, s.r.o. 2020 right-author's photo.

Despite the ongoing activities, the village's landscape structure is still dominated by agricultural land (53.46\%), while arable land covers $30.15 \%$ of the area. Important landscape components of the village are permanent grasslands (22.67\%) and forest areas $(27.53 \%)$. Built-up areas cover only $4.37 \%$, water areas $2.47 \%$ and other areas $12.15 \%$.

The historical landscape structure is preserved mostly in the central part of the village. It presents Hniezdne as a town-type residence with a preserved medieval town center, a lenticular square.

We follow distinctive interventions into the use of the landscape during the last seventy years. In 1950, the use of sites is obvious for agricultural purposes on the orthophoto map. They include the surface of the wild built-up areas that are made up of buildings of a single peasant cooperative of Hniezdne. We follow the results of previous land transformation in 2017. In 2001, industrial land related to BGV, s.r.o. Hniezdne and its production of alcohol drinks appeared. In 2012, recreational land began to grow in Nestville Park (Figure 6). Based on the reconnaissance of the terrain, we compiled a DPSIR model (Table 3).

There is a strong business entity in the village, which initially started a business in spirit production. It has expanded its portfolio with activities in the area of today's extremely popular gastronomic tourism; thus de facto directly capitalizing its production. In this context, we think that a one-sided orientation to the gastronomy segment can also be a weakness of the area in question in the case of, e.g., a decline in interest in this phenomenon. A potential threat is the loss of authenticity (the use of English building names, as well as the offering of a product - whiskey, which is not typical for this region). The potential environmental burden may be closely related to local production (distillery, brewery), requiring high pressure on water consumption. 
Table 3. DPSIR model for Hniezdne.

\begin{tabular}{cl}
\hline Component & \multicolumn{1}{c}{ Interpretation } \\
\hline D (driving force) & $\begin{array}{l}\text { cultural and historical heritage (connection to the historical foundations of distillery from the 18th } \\
\text { century, monument zone), public interest, quality environment, advantageous transport location, } \\
\text { investor interest, new trends in tourism, proximity to large tourist source regions, effective marketing of } \\
\text { the area, presentation of the territory in the media }\end{array}$ \\
\hline $\mathrm{P}$ (pressure) & $\begin{array}{l}\text { increase in waste production, increased water consumption, impact on water quality, increase in built-up } \\
\text { area (by 5.9\% since 2011), increased traffic in the municipality, impact on local culture }\end{array}$ \\
\hline $\mathrm{S}$ (state) & $\begin{array}{l}\text { minimal air pollution, no significant source of pollution, land use was added, other non-agricultural land } \\
\text { area decreased by 2\%, land acculturation, preference of current trends, revitalization of agricultural } \\
\text { brownfield }\end{array}$ \\
\hline $\mathrm{I}$ (impact) & $\begin{array}{l}\text { increasing the cost of building infrastructure, supporting local agriculture, new jobs, increasing the } \\
\text { employment of the local population, impact on protected areas, new types of experiences for visitors, } \\
\text { loss of community identity }\end{array}$ \\
\hline $\mathrm{R}$ (response) & $\begin{array}{l}\text { contribution to the taxes of the municipality, completion of tourism products, support of agritourists, } \\
\text { restoration of spas based on the tradition of the 19th century }\end{array}$ \\
\hline
\end{tabular}

Source: Own preparation.

\subsubsection{Podhájska}

An example of a transformed agricultural landscape, which has significantly focused on tourism activities, is the village of Podhájska. The area of the village is $11.12 \mathrm{~km}^{2}$ and the village has 1015 inhabitants (as of 31 December 2019). The village is situated in its most productive agricultural part. In the village, agricultural land covers $77.1 \%$, while the degree of plowing reaches $81.2 \%$. Permanent grasslands cover $7.4 \%$, gardens $3.16 \%$ and orchards $2.13 \%$. Non-agricultural land accounts for $22.9 \%$, of which $10.3 \%$ is forests and $9.2 \%$ is built-up areas. Water areas are $1.0 \%$ and other areas are $2.44 \%$.

The stimulus for the development of tourism in the village was the discovery of thermal mineral waters in the 1980s. Maximum water temperatures are up to $80^{\circ} \mathrm{C}$ and heat output is 14.42-19.2 MWt. From a chemical point of view, these are waters of the sodium chloride type with mineralization up to $19.6 \mathrm{~g} / 1$. They represent marinogenic waters with varying degrees of degradation of marine salinity $[57,58]$.

Based on thermal strongly mineralized water, a thermal swimming pool was built in Podhájska in 1973, to which the Aquamarin Wellness Center was added in 2012 (Figure 7). At present, the thermal swimming pool complex consists of 10 pools during the summer season, of which 4 pools have geothermal water. Natural solariums complement the water attractions. During the winter season, there is a relaxation and reconditioning complex. The Aquamarin Wellness Center consists of an indoor pool world, an outdoor pool world and a vital world. The indoor pool world consists of 5 pools and the outdoor pool world includes 2 pools with thermal water and 2 pools with regular water [59].

Sports grounds and accommodation facilities complete the recreational area of the swimming pool. In the area of the swimming pool is located Hotel Borinka (105 beds), the campsite at St. Urban ( 30 places for caravans and 60 places for tents) and the cottage complex Bungalovy ( 64 beds). Catering services are offered by the Jasmín restaurant (90 seats). Other accommodation capacities in Podhájska are provided by B\&Bs, apartment houses or private accommodation in the village and the surrounding villages. With its natural sources of thermal water, the village of Podhájska has gradually transformed into an important tourist center not only in the Nové Zámky district but also in the Nitra self-governing region. However, it is also attractive to foreign visitors, especially from the Czech Republic, Germany, Poland and Hungary. The Podhájska thermal swimming pool ranks 4th, following resorts such as Aquacity Poprad, Bešeňová Water Park and Aquapark Tatralandia, with 781,568 visitors and a total revenue of EUR 6.9 mil. 

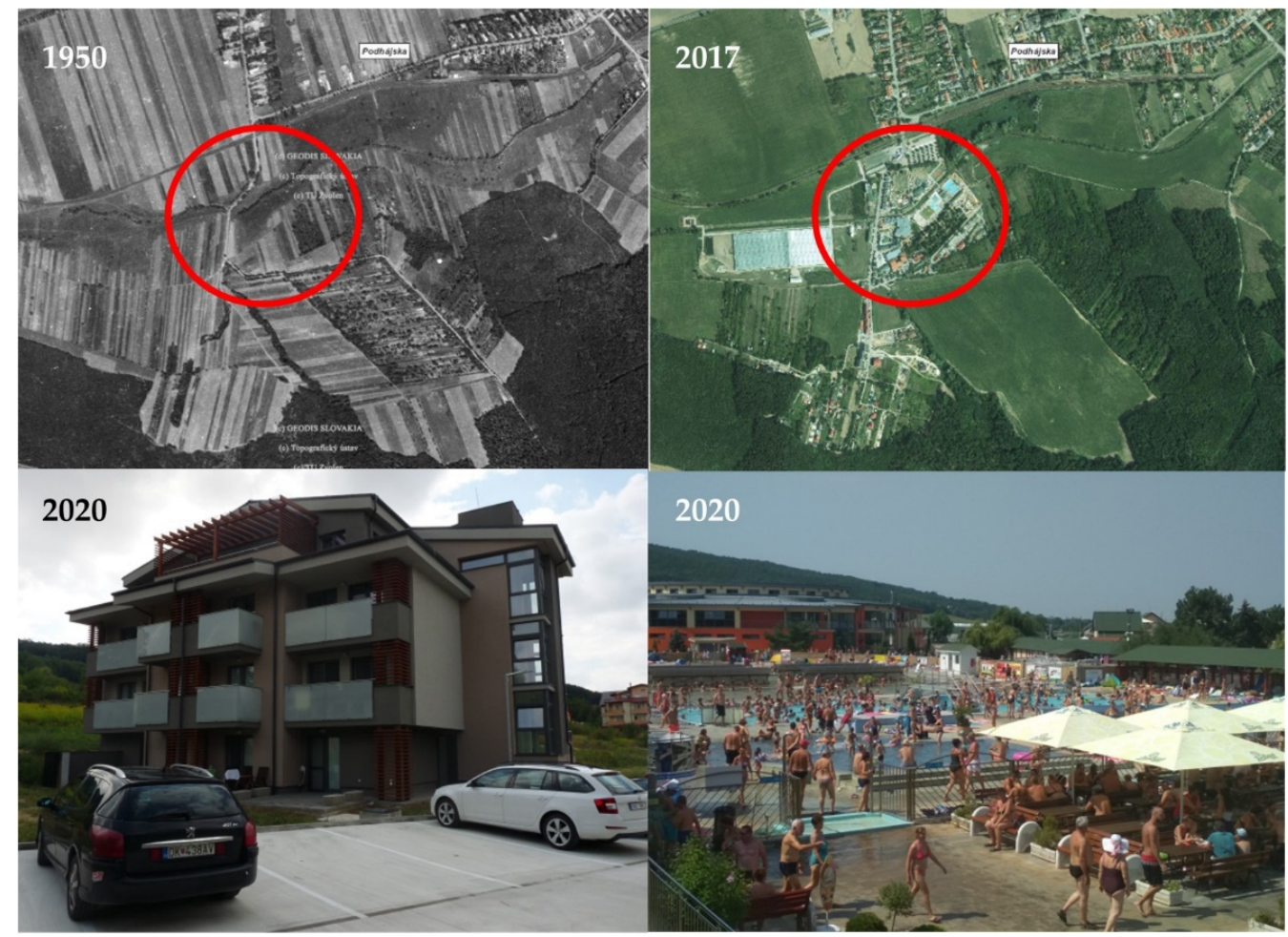

Figure 7. Visual interpretation of the Podhájska site. Source: 1950-Adapted with permission from ref. [37]. Copyright 2021 GEODIS SLOVAKIA, s.r.o. Bratislava, Topografický ústav Banská Bystrica. 2017-Adapted with permission from ref. [38]. Copyright 2021 GKÚ Bratislava, NLC Zvolen. 2020-author's photo.

The location presents a very significant change in land use in the time horizon of 1950 to 2017. The sole use of territory for agricultural purposes is apparent in the orthophotomap from 1950. In the following periods of the 20th and 21st centuries, several campuses with different uses of the land, as presented in the orthophotomosaic from 2017, have been added. These campuses also include areas of accommodation and catering facilities, road communications and parking and housing stock (Figure 7), based on the obtained information of statistical data and reconnaissance of the terrain (Table 4).

Table 4. DPSIR model for Podhájska.

\begin{tabular}{|c|c|}
\hline Component & Interpretation \\
\hline $\mathrm{D}$ (driving force) & $\begin{array}{l}\text { potential of thermal water, healing effects of thermal water, sufficient capacity of water sources, } \\
\text { increasing interest of visitors in services, development of the village, overall development of tourism, } \\
\text { effective marketing }\end{array}$ \\
\hline $\mathrm{P}$ (pressure) & $\begin{array}{l}\text { increase in waste production, increased consumption of water and thermal water, increased frequency of } \\
\text { transport, change of land use, loss of authenticity of the village, need to build tourism infrastructure, } \\
\text { increase in land and real estate prices, increase in attendance }\end{array}$ \\
\hline S (state) & $\begin{array}{l}\text { minimal air pollution, change of use of real estate, deterioration of surface and groundwater quality, } \\
\text { duality of local community in perception of tourism, marginalization of local population, rising land } \\
\text { prices, excessive tourism, outflow of young population from the village, irritation by the tourists }\end{array}$ \\
\hline I (impact) & costs of building infrastructure, new jobs, increasing employment in the municipality, new services \\
\hline $\mathrm{R}$ (response) & $\begin{array}{l}\text { contribution to the taxes of the municipality of tourism, building of the infrastructure of the municipality, } \\
\text { completion of tourism products, orientation to the spa tourism }\end{array}$ \\
\hline
\end{tabular}


The village's tourism is realized only using the main attractor-thermal water-while emphasis should be placed on the offer of more variability, which is significant.

The village is also beginning to show the harmful effects of tourism, such as tourist inflation, the growth of duality in the community, as well as signs of excessive tourism.

\subsection{5. Čierny Balog}

The village of Čierny Balog, the largest village in Slovakia with an area of $147.10 \mathrm{~km}^{2}$, is located in Central Slovakia. In 2019, the village had 5090 inhabitants. It is found in the Vydrovo locality and reaches an altitude of about $570 \mathrm{~m}$. This area's settlement dates back to the 15th century and is related to pastoralism; later, lumbering settlements were established in this area, which supplied wood from the surrounding forests near the mines and smelters. As per Supuka and Štefunková [60], it represents a forestry type of cultural landscape. The current landscape structure is also strongly influenced by the historical development of the area. The village is dominated by forests-78.9\%. Within this share, commercial forests dominate (92.2\%). Agricultural land is less than 19\%, permanent grasslands (17.3\%), water areas $(0.21 \%)$, built-up areas $(0.99 \%)$ and other areas $(1.03 \%)$.

The harvested wood was transported in the first phase by water. The growing demand of industrial factories for wood led to constructing a unique and efficient transport system for its time-the forest railway. It began to operate in 1909. The end of the operation of the Čiernohronská Railway was set for 31 December 1982. By the Slovak communist government's decision, the entire railway and machinery were to be scrapped by 1985 . Her rescue owed to a few enthusiasts and their personal courage. An important step was the registration of the Čiernohronská Railway in the Central State List of Cultural Monuments (1982). The resumption of operation on the railway took place on 1 May 1992. To this day, visitors have the opportunity to drive in period wagons powered by steam locomotives.

The historical development and traditions of Čierny Balog, inspired the company Lesy SR š. p. to create the Forest Museum, opened to the public in 2002 on an area of 140 ha in Vydrovská Dolina Valley. Its goal is to introduce visitors to foresters and forest workers from the past to the present. On an area of 140 ha, of which 116 ha is occupied by forest, the open-air museum has more than 70 thematic stops. In the open-air museum area, visitors can also see an eco-gallery, a symbolic forest cemetery, an information center, a didactic shelter or a map of Slovakia's forestry.

The open-air museum's construction is not completed, and new attractions are added every year [61]. The symbiosis of these two elements so typical for this area (technical monument-forest railway and open-air forest museum) (Figure 8) has brought visitors an extremely attractive tourist product. In addition to relaxation, it also offers an educational moment through forest pedagogy.

A comparison of 1950 and 2017 orthophotomaps shows an increase in afforestation in 2017. Through visible afforestation, the area has come close to fulfilling the principle of sustainability. This is also documented by movable and immovable exhibits that symbolize the history of the site, e.g., mountaineering and steam locomotives (Figure 8). 

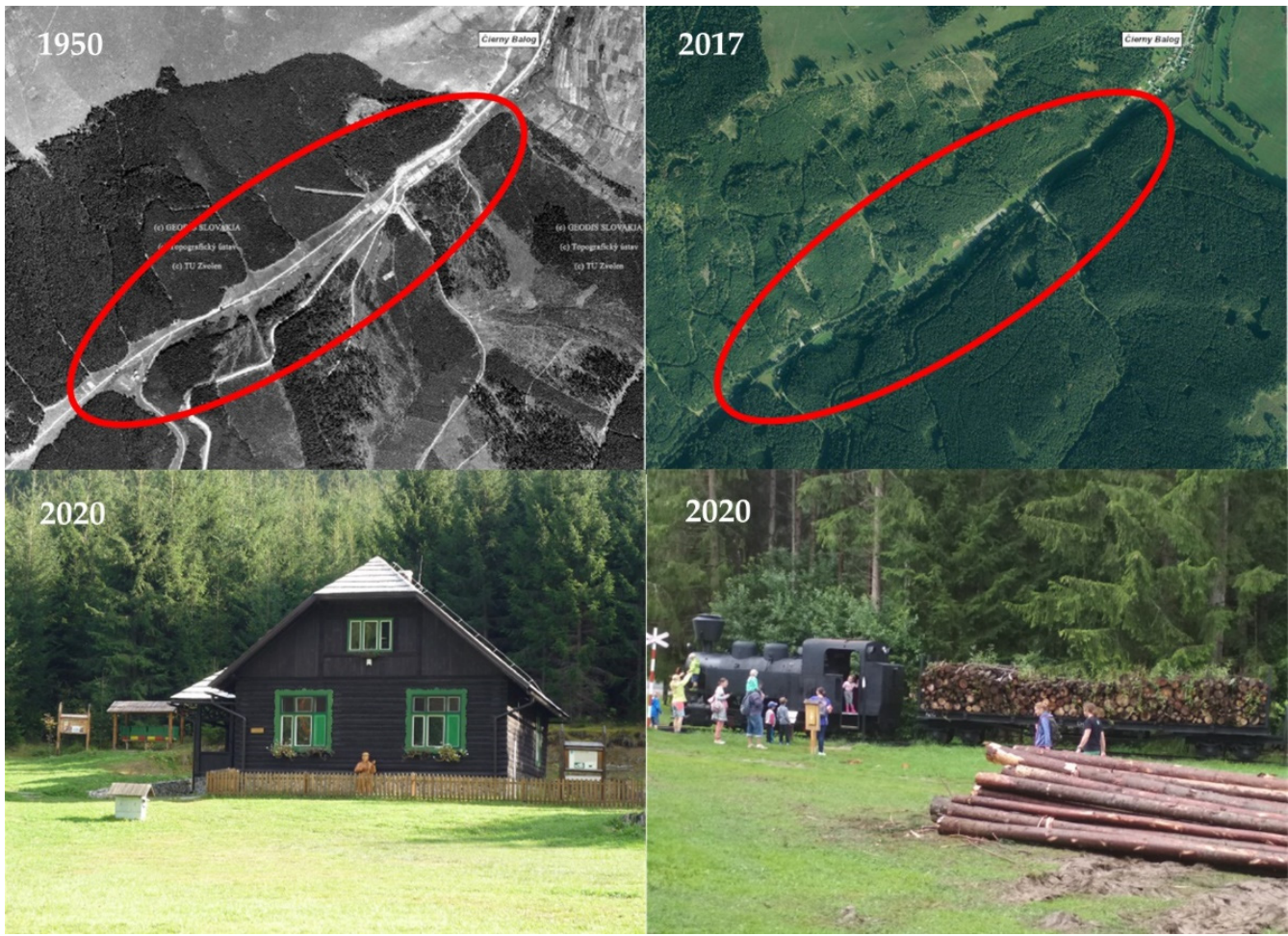

Figure 8. Visual interpretation of the Čierny Balog (Vydrovská Dolina Valley) site. Source: 1950Adapted with permission from ref. [37]. Copyright 2021 GEODIS SLOVAKIA, s.r.o. Bratislava, Topografický ústav Banská Bystrica. 2017-Adapted with permission from ref. [38]. Copyright 2021 GKÚ Bratislava, NLC Zvolen. 2020-author's photo.

Based on the obtained information of statistical data and reconnaissance of the terrain (Table 5), the area presents a strong story, transformed into an offer of a sustainable tourist products, which the open-air forestry museum in combination with the old-fashioned steam railway is. The municipality must ensure better conditions, especially in terms of car parking and expanding the catering facilities' capacity.

Table 5. DPSIR model for Čierny Balog.

\begin{tabular}{cl}
\hline Component & \multicolumn{1}{c}{ Interpretation } \\
\hline $\mathrm{D}$ (driving force) & $\begin{array}{l}\text { presentation of the history, cultivation and importance of the forest, a demonstration of traditional forest } \\
\text { management from the Horehronie region, timber transport by old fashioned railway, the interest of } \\
\text { visitors, the authenticity of the environment, the preservation of the traditional culture of the region }\end{array}$ \\
\hline $\mathrm{P}$ (pressure) & $\begin{array}{l}\text { increased waste production, increased water consumption, increased traffic in the village, problems with } \\
\text { parking }\end{array}$ \\
\hline $\mathrm{S}$ (state) & $\begin{array}{l}\text { no significant air pollution is recorded, no significant source of pollution has been added, increased noise } \\
\text { in the main season }\end{array}$ \\
\hline $\mathrm{I}$ (impact) & infrastructure construction costs (catering facilities, parking spaces), new jobs, craft support \\
\hline $\mathrm{R}$ (response) & $\begin{array}{l}\text { contribution to the municipality's taxes, traditional logging and attractive historical railway is a } \\
\text { sustainable product of tourism }\end{array}$ \\
\hline
\end{tabular}

Source: Own preparation.

We see the opportunity to develop tourism mainly in the expansion of the offer, e.g., during the summer months, concerts by folk bands or observations of the night sky, with the astronomer's live interpretation. 


\subsection{6. Špania Dolina}

Špania Dolina, as an example of a mining landscape, is located in Central Slovakia. The area of the village is $12.72 \mathrm{~km}^{2}$ and the village has 215 inhabitants (as of 31 December 2019). The village center lies at an altitude of $711 \mathrm{~m}$. The current landscape structure of the village is dominated by $79.1 \%$ forests ( $36.8 \%$ special-purpose forests). Agricultural land covers $16.9 \%$ and permanent grasslands $15.7 \%$. Water areas make up $0.2 \%$, built-up areas $1.78 \%$ and other areas $2.05 \%$. Since 1978, part of the village has been included in the protection zone of the Low Tatras National Park. In the village are Special Area of Conservation Baranovo and the Special Protection Area Vel'ká Fatra.

The village was known in the world for the mining and processing of copper ore. An extensive, unified mining complex was created here with massive towing shafts, long, well-equipped towing tunnels and complicated machines and equipment. The village experienced extreme prosperity in 1496-1546 [62] when the Thurzo-Fugger copper mining company controlled mining. During this period, Špania Dolina and its surroundings was one of the wealthiest areas in the world. From the 17th century, the yield of copper ores from the mines in Špania Dolina gradually decreased.

Thanks to its unique location and, mostly, the remnants of mining activities (350-yearold mining works), the village has become a popular tourist destination. In contrast, in all current documents, the village is listed as a recreational village [63] (Figure 9). The spoil tips-the most dominant artificially created landscape forms in the natural environmentare located in the area at altitudes of 430-900 m. The uncovered, unforested Maximilián spoil tip comes into contrast with the surrounding landscape, making it an essential and characteristic element of the area. A dense network of mining trails is currently used as bike paths, hiking trails and, in the winter months, as ski trails.

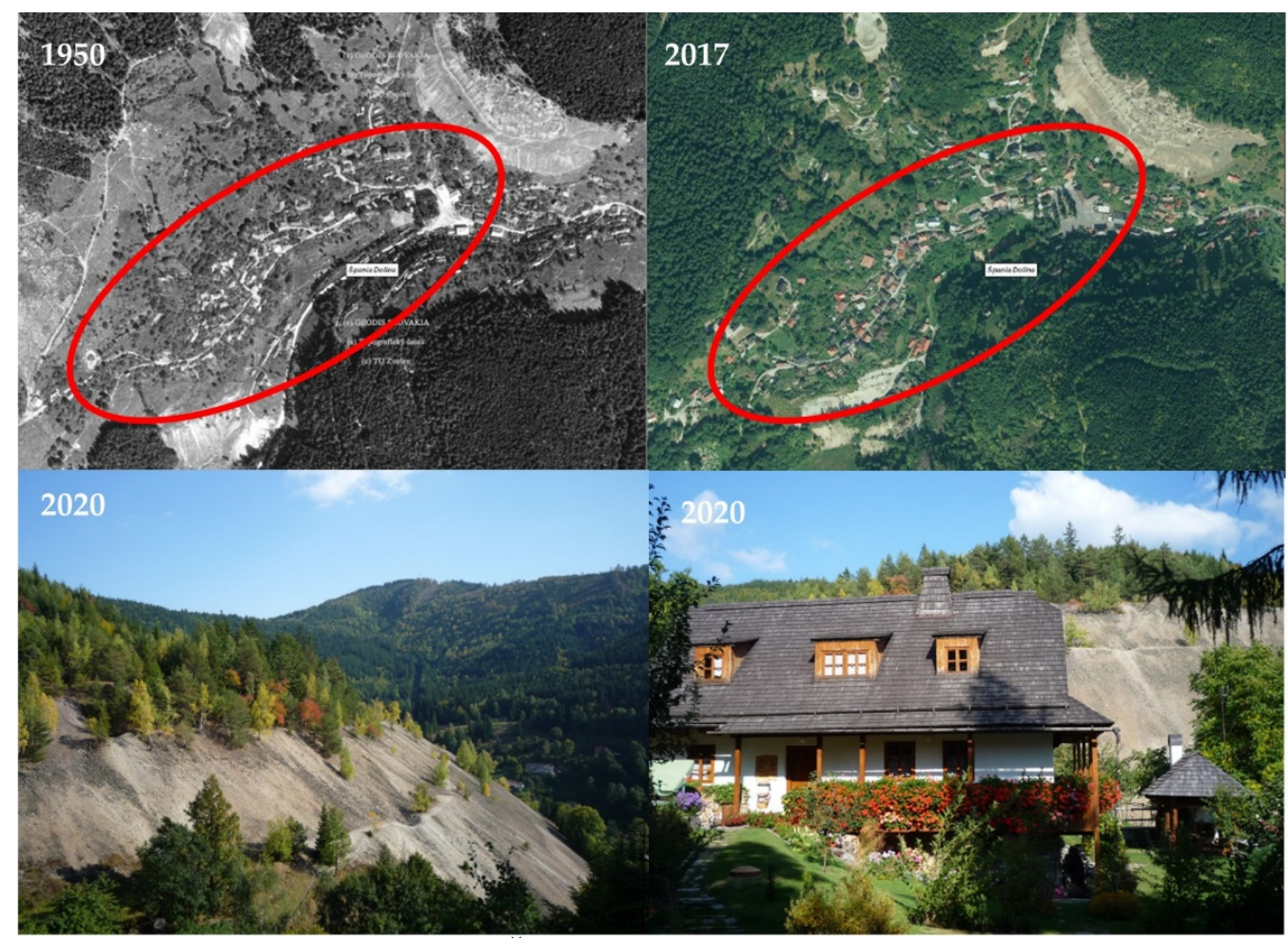

Figure 9. Visual interpretation of the Špania Dolina site. Source: 1950-Adapted with permission from ref. [37]. Copyright 2021 GEODIS SLOVAKIA, s.r.o. Bratislava, Topografický ústav Banská Bystrica. 2017-Adapted with permission from ref. [38]. Copyright 2021 GKÚ Bratislava, NLC Zvolen. 2020-author's photo.

It is also attractive with its spatial arrangement, representing a unique valuable urban complex consisting of folk, technical, church and public buildings. The village's dominant 
feature is the church, built on a terrain terrace; the mining astronomical clock is one of the attractive sites, which represents a model of a typical Špania Dolina mine from the 16th century. The famous copper tradition is also reflected in the Museum of Copper and Lace (a product by which families improved their living conditions). The mining history has recently been transformed into a mining nature trail, which acquaints the visitor with the village's glorious past using information boards or a guide.

A comparison of the 1950 and 2017 ortophotomaps is documented by the fact that the territory in question is conserved. Shown in the orthophotomosaic from 2017 is a more significant proportion of forest, with a heap in the southwestern part of the village showing signs of succession. Houses in the village are transformed into recreational buildings with a view of cultural monuments or old mining works, based on the obtained information of statistical data and reconnaissance of the terrain (Table 6).

Table 6. DPSIR model for Špania Dolina.

\begin{tabular}{cl}
\hline Component & \multicolumn{1}{c}{ Interpretation } \\
\hline $\mathrm{D}$ (driving force) & $\begin{array}{l}\text { Medieval mining and its historical heritage, to preserve and maintain the characteristic manifestation of } \\
\text { mining activities (recreational, cultural, social and educational function), the attractiveness of the area, } \\
\text { society's demand for tranquility in less frequented tourist areas, high-quality air, advantageous } \\
\text { geographical location, monuments' authenticity }\end{array}$ \\
\hline $\mathrm{P}$ (pressure) & $\begin{array}{l}\text { increased traffic density, worn state of the communications, the requirement to build accommodation } \\
\text { facilities, endangering the stability of selected forms of relief, increased interest in real estate, preferring } \\
\text { the needs of visitors to residents }\end{array}$ \\
\hline $\mathrm{S}$ (state) & undesired change of landscape character, landslides \\
\hline $\mathrm{I}$ (impact) & $\begin{array}{l}\text { infrastructure construction costs, impact on the biodiversity of the area, rising real estate prices, } \\
\text { marginalization of the needs of residents }\end{array}$ \\
\hline $\mathrm{R}$ (response) & $\begin{array}{l}\text { transformation of history into products of tourism, cognitive tourism, objects respecting the monument } \\
\text { values of the area, construction of car parks outside the monument reservation, lace-creating workshops }\end{array}$ \\
\hline
\end{tabular}

Source: Own preparation.

The site has an engaging story based on local history. The problem or the weakness is the limited space for building a possible tourist infrastructure, which results from the morphology of the relief and the monumental character of the area. The opportunity is a connection to the existing Barborská route with potentially growing tourist importance. We do not anticipate an environmental burden in the area.

\subsection{Life Cycle of Transformed Tourism Sites}

The life cycle model of a tourism center is one of the most popular ways of evaluating the stage of development of a locality or center. The commonly used Butler model [42] can be effectively supplemented with the phases and conditions of sustainability and ecological stability, following the current requirements for the sustainable development of tourism, based on the proposals of Szromek et al. [33].

In evaluating our selected tourist sites, we monitor their various phases of the life cycle as centers of tourism (Figure 10). 


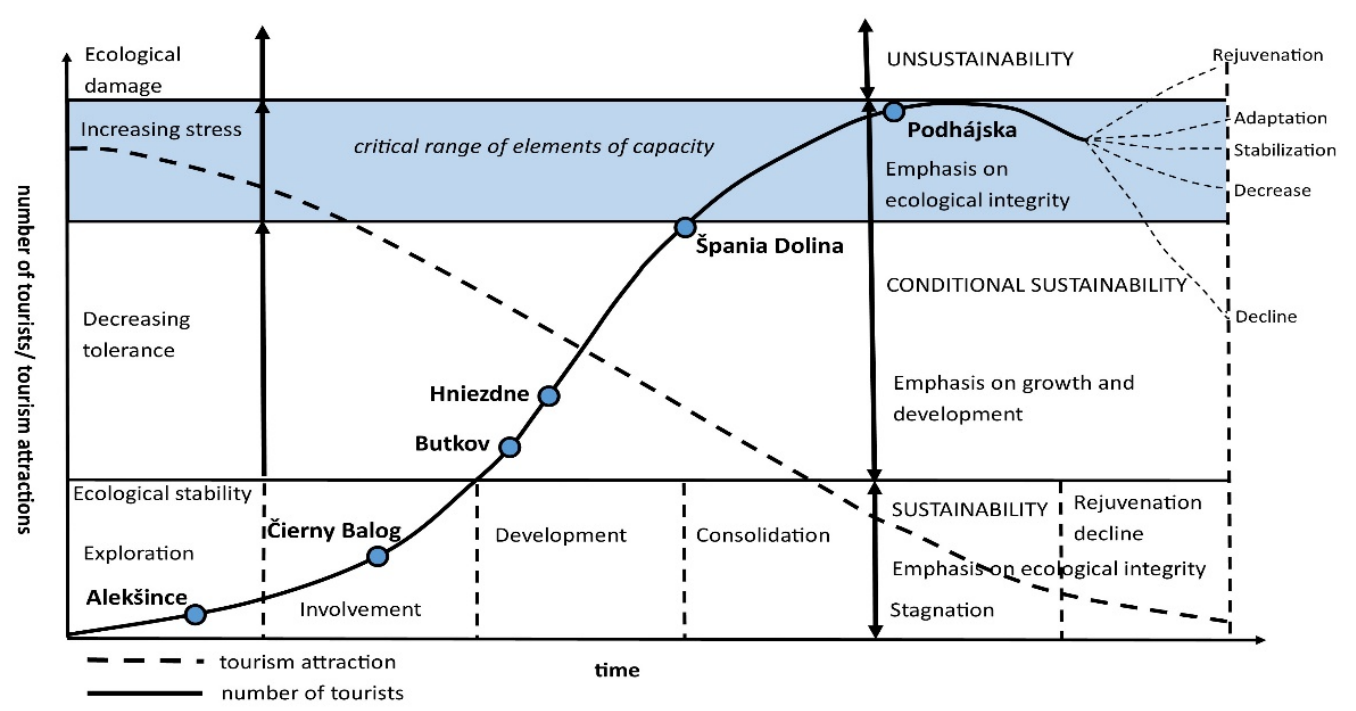

Figure 10. Life cycle of transformed tourism localities in Slovakia concerning sustainable development. Source: [33,42], own processing, 2021.

Based on the characteristics of the tourism, the village of Alekšince can be perceived as being in the exploration phase. The village's dominant feature in terms of tourism development is the location in which the Museum of Socialism and the Cold War is located. The site represents a new area, sporadically discovered by small groups of tourists looking for a change of environment, fun, uniqueness and attraction. In the locality case, the biggest attraction is the authenticity of the environment, which is unknown to the current young generation. An important attraction is also the educational aspect of the locality and its uniqueness in Slovakia. The museum is gradually beginning to respond to the positive feedback from visitors with other activities. The destination's development is very slow, without significant landscape interventions, and currently does not include any tourist infrastructure construction. The landscape itself shows almost no changes in the structure of the land cover. Sustainable development of the territory is typically based on functioning processes typical for the agricultural landscape. There are no significant new anthropogenic interventions in the locality. Pressures on its ecological stability do not threaten the museum's territory; stress factors are minimal, as well as the effect of risk factors on individual components of the environment.

The Čierny Balog locality is in the phase of penetration or involvement. It is a location where tourists regularly appear, thus encouraging local people to provide simple services, especially in accommodation and meals. In 2006, it provided 165 beds for accommodation which, in 2005, was 261 beds [64]. The location is already relatively well known to the public, mainly due to promotional activities. The number of visitors is gradually increasing. Their activities have only a minimal impact on local societies, the landscape and its ecological environment. Sustainable development is still prevalent in the landscape with minimal manifestations of risk factors, and with small anthropogenic interventions in the environment. The locality principle is instead to preserve the authenticity of the area and cultural and historical values of the area and offer a demonstration of our ancestors' way of life. The site does not prefer excessive transformation and significantly altered infrastructure, which would have a counterproductive effect in this environment and could destroy authenticity elements, but is based on preserving its character and uniqueness.

The Butkov and Hniezdne localities are in the development phase while including the higher development stage in Nestville Park in Hniezdne. This is expected for both localities as they are currently well known and gradually popular tourist destinations, to which a larger number of tourists come regularly. The original parts of the localities have undergone a transformation process in recent years, and the types of the landscape have changed in the tourist parts. The primary role in the development of the destination is 
given to priority investors who respond to visitors' demand in their offer. On top of Butkov, construction has taken place since 2012. In the near future, the planned construction of a seating area is planned, and the construction of a chapel and social zone for pilgrims. In the locality of Hniezdne, it is also in the zoning plan of the village to create a complex zone of a production and recreational character with an agrotourism focus in Nestville Park. Employment is increasing, the quality of life is improving and endogenous regional development is being implemented. The development of tourism also encourages the emergence of artificial tourist attractions in the form of products, such as parks interfering with the locality's culture and authenticity, responding primarily to the effect of current trends. The original character of the destinations is gradually changing in the localities. Among the visitors, groups of individual mass tourists are the majority, having higher demands for the quality of infrastructure and services. Impacts on the landscape are significantly visible in the localities at this stage. The shift from a state of sustainable development to a state of conditional sustainable development and the sustainability of the area must be purposefully incorporated into a tourism center's construction. We observe an evident anthropogenic pressure in the localities, which is reflected in the decreasing tolerance of ecosystems, in the landscape's growing stress and in decreasing the area's ecological stability. Processes of environmental and ecological damage to the landscape are also observed on a small scale.

The Špania Dolina tourism site is in the consolidation phase. Due to its unique historical landscape structure, which the locality has among its priorities and tries to adhere to consistently, it has already reached a position in its life cycle characterized by the most advanced stage of development. Tourists already exceed the number of locals. The housing stock has not changed over recent decades; the village has 220 homes, including 50 tourist cottages [65]. The area's tolerance for change is very low, as the area has undergone significant changes during its historical development. Its stability can be easily changed and even minimal pressure on the landscape's carrying capacity can cause severe damage and devastation. Interventions in the territory are due to the inclusion of the site in the Nízke Tatry National Park. At the same time, the village has been targeted since 1979 for the conservation of folk architecture with established conditions for construction and economic activities.

In the phase of stagnation, especially when considering sustainable development, is the locality of tourism of Podhájska. Central to its character (center of international importance), offer (year-round operation) and infrastructure (200 beds in the swimming pool area, over 1500 beds in the village, various kinds of catering facilities) is a period of full maturity within the tourism industry. In terms of sustainable development, there are multiple problems, such as excessive and unbearable growth of visitors at a limited capacity, increasing water consumption and growth of municipal waste. The daily number of visitors is growing, reaching an average of 5000 people per day, which represents an annual water consumption of $101,000 \mathrm{~m}^{3}$ per year only for tourism in the village. The amount of waste is growing, which in 2011 was 245.06 tons, in 2015 it was 413.27 tons and in 2016 it was 598.7 tons [66]. Environmental damage has reached a top position in the landscape and the landscape has significantly changed its appearance, structure and function. The number of tourists already exceeds the number of residents and is still growing, along with growing profits. While in 2006, 545,000 visitors visited the swimming pool, in 2009, there were 560,000 visitors and in 2018 , there were 782,000 visitors. In the structure of the landscape, a significant recreational area is evident, which has become dominant. The appearance of the village has changed significantly in recent years. In accordance with Antrop (2004) [13], we state that the traditional rural village discovered by tourism was affected by morphological and functional urbanization, which caused profound social, economic and cultural changes. The original houses of the local population have been replaced by buildings that disrupt the rural character of the development. Due to the village's excessive development for tourism needs, there are already manifestations of tension between residents who are not involved in tourism and tourists, limiting and affecting their daily lives. Tourism in the 
village is gaining mass character. Tourism is beginning to be perceived by some residents as a burden, with the first signs of excessive tourism appearing. The local population cannot keep a sufficient pace to respond to rising land and real estate prices, and the risk is that the young population may lose interest in living in the village.

\section{Discussion}

Landscape transformation is a typical process responding to anthropogenic needs and requirements. In many regions and localities, not only in Slovakia, this is also conditioned by the interest in tourism development. It brings new impulses to the landscape, which may manifest themselves in the future as positive or negative changes. However, changes from an environmental point of view are also noticeable and they can take on a positive and negative character. Therefore, it is essential to prioritize their sustainable development when planning the development of tourism centers. It is important that their economic and social development is aligned with environmental development and that it accepts the requirements of sustainability.

The DPSIR method was used in the first part when evaluating the selected localities. The common practice is that the model is also used in tourism to assess its impact on the environment. However, in most work, application is usually focused only on the effects of tourism on the natural components of the environment. In accordance with Pásková [31], we extended the assessment of the impacts of tourism to other components of the environment in the causal DPSIR model. We evaluated, e.g., impacts on the transport environment (increase in traffic frequency), housing environment (change in the functional use of housing stock, increasing land prices), cultural and social environment (loss of identity, acculturation) or social environment (marginalization of the local population, a massive level of tourism). At the same time, we also analyzed the positive effects of tourism on the environment, thus limiting the unilateral assessment of changes in the impact of tourism. We consider such a modified methodology to be significantly more objective and more applicable. We verified its use in dimensionally different localities.

In the next part of the work, we apply another method used to evaluate tourism issues - the life cycle of a tourist destination. This model is a useful conceptual framework for studying the dynamics and sustainability of destination environments. It creates a suitable platform for verifying and applying multiple concepts of tourism studies, in particular load capacity and social change. The concept of the method is usually based on monitoring the load capacity of the destination in terms of the number of visitors and its interrelated social changes [67-69]. Combination of the destination cycle concept with social change theory is mentioned by Snepenger and Reiman et al. [70]. In line with Wall [71], it is an endogenous theoretical concept of a tourism study that has a high descriptive and exploitation value.

The advantage of the model used can be perceived mainly in the fact that it considers the temporal and spatial development of the tourism industry, and its effects on the natural and social environment of the tourism site. Other information provided is development of the composition and relationships of key actors involved in the various stages of the destination life cycle. Based on the works of Szromek et al. [33], we have incorporated into the model other essential characteristics through which we also address the conditions of sustainable tourism development and the ecological stability of the site. We see the pros again in the complexity of evaluating tourism sites and the current strongly preferred trend and the necessity of applying environmental perspectives on the issue.

Other possibilities for assessing tourism destinations that would be interesting in the future to apply include, e.g., the concept of beneficial capacity of territories. It is established upon professionally supported expertise and the socially acceptable maximum load of territories with anthropogenic influences, so irreversible changes lead to reducing natural components and socio-cultural environments. Authors [72-75] have covered the topic in more detail in other articles. In applying the concept, it is important to know the level of environmental vulnerability and the current way to use the solved territory by inventory 
and land use. Examples are, e.g., the work of Nicu and Stoleriu [76], who evaluate the changes to land use around the churches of Moldavia. They use photo interpretation through orthophotos and historical maps at multiple times, indicating changes in the landscape and the anthropogenic environmental changes. Similarly, Schupl et al. [77] and Gerard et al. [78] have studied past and future land use changes in the European Union's cultural landscapes. According to these authors, cultural landscapes show strong variation of changes under different scenario conditions in terms of future landscape change. Olsson et al. [79] interpret the landscape changes in two mountain valleys in central Norway over the period 1960-1990 in relation to differential land use and environmental factors. Assessment of agricultural land changes at selected locations of Slovakia using orthophotomaps from several time periods is also present in the works of Masný and Zaušková [80] and others [81-83].

In six selected model examples, the transformation of the landscape into a recreational landscape is the result of a combination of the potential of the territory and the creativity of humankind. Humankind changes the potential of the landscape into a form usable by tourism. Most model territories develop with respect to the principle of sustainable development (Alekšince, Butkov, Čierny Balog and Špania Dolina). The opposite is true for the development of the village of Podhájska. The direction of development of the village of Hniezdne is borderline. It will depend on the representatives of the municipality and the business plans of the owners of Nestville Park.

The importance of evaluating the transformation processes in a landscape is more than necessary, especially when we want to assess the character of the landscape in the specific site, its identity but also the direction. In the development of the territory, they can provide valuable information for future decision-making processes, which should be primarily responsible for and in accordance with the principles of sustainable development. The basis on which to build effectively is information related to changes in land use. Due to the dynamism of changes, new challenges arise in the research of the landscape, and not only the tourist landscape.

Author Contributions: Conceptualization, D.O., M.N. and A.K.; methodology, D.O., M.N. and A.K.; formal analysis, D.O., M.N. and A.K.; investigation, D.O., M.N. and A.K.; resources, A.K.; writingoriginal draft preparation, D.O., M.N. and A.K.; visualization, D.O.; supervision, D.O., M.N. and A.K.; project administration, M.N. All authors have read and agreed to the published version of the manuscript.

Funding: This research was funded by the Cultural and Educational Grant Agency (KEGA) of the Ministry of Education, Science, Research and Sports of the Slovak Republic, grant number 015UKF-4/2019 and by the Slovak Research and Development Agency (APVV) under Contract no. APVV-18-0185.

Data Availability Statement: Not applicable.

Conflicts of Interest: The authors declare no conflict of interest.

\section{References}

1. Gregorová, B.; Hronček, P.; Tometzová, D.; Molokáč, M.; Čech, V. Transforming Brownfields as Tourism Destinations and Their Sustainability on the Example of Slovakia. Sustainability 2020, 12, 10569. [CrossRef]

2. Sołjan, I.; Liro, J. New pilgrimage centre in Kraków's Łagiewniki-Borek Fałęcki district (In Polish: Nowe centrum pielgrzymkowe w krakowskiej dzielnicy Łagiewniki-Borek Fałęcki). Peregr. Crac. 2014, 25, 135-151.

3. Sołjan, I.; Liro, J. The changing roman catholic pilgrimage centres in Europe in the context of contemporary sociocultural changes. Soc. Cult. Geogr. 2020, 21. [CrossRef]

4. Gunn, C.A. Landscape Assessment for Tourism. In Proceedings of Our National Landscape: A Conference on Applied Techniques for Analysis and Management of the Visual Resource, Incline Village, NV, USA, 23-25 April 1979; Pacific Southwest Forest and Range Experiment Station: Berkeley, CA, USA, 1979; pp. 409-414.

5. Chrenka, B.; Ira, V. Transformation of tourist landscapes in mountain areas: Case studies from Slovakia. Hum. Geogr. 2011, 5, 13-20. [CrossRef]

6. Hof, A. Urban and tourist land use patterns and water consumption: Evidence from Mallorca, Balearic Islands. Land Use Pol. 2011, 28, 792-804. [CrossRef] 
7. Petrikovičová, L.; Krogmann, A.; Fialová, D.; Svorad, A. Intensive tourist-related urbanisation impacts on a mountain village: The case study of Vel'ká Lomnica in Slovakia. Geogr. Pol. 2019, 92, 395-408. [CrossRef]

8. Kadlecová, V.; Fialová, D. Recreational housing, a phenomenon significantly affecting rural ares. Morav. Geogr. Rep. 2010, 18, 38-44.

9. Hughes, N. 'Tourists go home': Anti-tourism industry protest in Barcelona. Soc. Mov. Stud. 2018, 17, 471-477. [CrossRef]

10. Martín Martín, J.M.; Guaita Martínez, J.M.; Salinas Fernández, J.A. An Analysis of the Factors behind the Citizen's Attitude of Rejection towards Tourism in a Context of Overtourism and Economic Dependence on This Activity. Sustainability 2018, 10, 2851. [CrossRef]

11. Žigrai, F. Dimensions and attributes of the cultural landscape (In Slovak: Dimenzie a znaky kultúrnej krajiny). Zivotn. Prostr. 2000, 34, 229-233.

12. Boltižiar, M.; Chrastina, P.; Kramáreková, H.; Lauko, V.; Šolcová, L. Landscape Research in Case Studies (In Slovak: Výskum Krajiny v Príkladových štúdiách), 1st ed.; FPV UKF: Nitra, Slovakia, 2014; p. 318.

13. Antrop, M. Landscape change and the urbanization process in Europe. Landsc. Urban Plan. 2004, 67, 9-26. [CrossRef]

14. Bürgi, M.; Hersperger, A.M.; Schneeberger, N. Driving forces of landscape change current and new directions. Landsc. Ecol. 2004, 19, 857-868. [CrossRef]

15. Hersperger, A.M.; Gennaio, M.P.; Veburg, P.H.; Burgi, M. Linking Land Change with Driving Forces and Actors: Four Conceptual Models. Ecol. Soc. 2010, 15. [CrossRef]

16. Lambin, E.F.; Turner, B.L.; Geist, H.J.; Agbola, S.B.; Angelsen, A.; Bruce, J.W.; Coomes, O.T.; Dirzo, R.; Fischer, G.; Folke, C.; et al. The causes of land-use and land-cover change: Moving beyond the myths. Glob. Environ. Chang. 2001, 11, 261-269. [CrossRef]

17. Ot'ahel', J.; Feranec, J. Research of changes in landscape cover to understand the development of the landscape (In Slovak: Výskum zmien krajinnej pokrývky pre poznanie vývoja krajiny). Geogr. Slovaca. 1995, 10, 187-190.

18. Ot'ahel', J.; Feranec, J. Research and mapping of land use: The past and the present in the context of Slovakia (In Slovak: Výskum a mapovanie využitia krajiny: Minulost' a súčasnost' v kontexte Slovenska). Geogr. Časopis. 2006, 58, $105-123$.

19. Burley, T.M. Land use or land utilization? Prof. Geogr. 1961, 13, 18-20. [CrossRef]

20. Prokopová, M.; Cudlín, O.; Včeláková, R.; Lengyel, S.; Salvati, L.; Cudlín, P. Latent Drivers of Landscape Transformation in Eastern Europe: Past, Present and Future. Sustainability 2018, 10, 2918. [CrossRef]

21. Plieninger, T.; Draux, H.; Fagerholm, N.; Bieling, C.; Bürgi, M.; Kizos, T.; Kuemmerle, T.; Primdahl, J.; Verburg, P.H. The driving forces of landscape change in Europe: A systematic review of the evidence. Land Use Pol. 2016, 57, 204-214. [CrossRef]

22. Global Land Programme. Available online: https://glp.earth/ (accessed on 13 March 2021).

23. Copernicus Land Monitoring Service. Available online: https:/ /land.copernicus.eu/pan-european/corine-land-cover (accessed on 13 March 2021).

24. Skowronek, E.; Tucki, A.; Huijbens, E.; Jóźwik, M. What is the tourist landscape? Aspects and features of the concept. Acta Geogr. Slov. 2018, 58, 73-85. [CrossRef]

25. Terkenli, T.S. Landscapes of Tourism: A Cultural Geographic Perspective. In Tourism and Environment, 2nd ed.; Briassoulis, H., Straaten, J., Eds.; Kluwer Academic Publisher: Dordrecht, The Netherland, 2000; Volume 6, pp. 179-202.

26. Gkoltsiou, A.; Terkenli, T.S. Tourism and landscape: Toward interdisciplinary analysis of tourist landscape structure. Tourismos 2012, 7, 145-164.

27. Knudsen, D.C.; Metro-Roland, M.M.; Soper, A.K.; Greer, C.E. (Eds.) Landscape, Tourism, and Meaning, 1st ed.; Ashgate Publishing: Farnham, UK, 2008; p. 157.

28. Hall, M.; Page, S.J. The Geography of Tourism and Recreation-Environment, Place and Space, 4th ed.; Routledge: London, UK, 2014; p. 448.

29. Wahab, S.; Pigram, J. Tourism, Development and Growth: The Challenge of Sustainability, 1st ed.; Routledge: London, UK, $1997 ;$ p. 302.

30. Zelenka, J. Selected Approaches to Sustainable Tourism Research. (In Czech: Vybrané př́istupy k výzkumu udržitelnosti cestovního ruchu). Czech Hosp. Tour. 2010, 6, 126-136.

31. Pásková, M. Tourism Environmentalism. (In Czech: Environmentalistika cestovního ruchu). Czech J. Tour. 2012, 1, 77-113.

32. Szromek, A.R. An Analytical Model of Tourist Destination Development and Characteristics of the Development Stages: Example of the Island of Bornholm. Sustainability 2019, 11, 6989. [CrossRef]

33. Szromek, A.R.; Kruczek, Z.; Walas, B. The Attitude of Tourist Destination Residents towards the Effects of Overtourism-Kraków Case Study. Sustainability 2020, 12, 228. [CrossRef]

34. Mariot, P. Geography of Tourism (In Slovak: Geografia Cestovného Ruchu), 1st ed.; VEDA: Bratislava, Slovakia, $1983 ;$ pp. 94-210.

35. Weiss, P.; Jankovičová, M.; Kurčová, E. Regionalization of tourism in the Slovak Republic (In Slovak: Regionalizácia Cestovného Ruchu v Slovenskej Republike), 1st ed.; Ministry of Economy of the Slovak Republic: Bratislava, Slovakia, 2005; pp. 6-88.

36. Maps of Slovakia (In Slovak: Mapy Slovenska). Available online: https://www.e-slovensko.cz/s/mapy (accessed on 30 March 2021).

37. Historická Ortofotomapa @ GEODIS SLOVAKIA, S.R.O. A Historické LMS @ Topografický ústav Banská Bystrica. Available online: https:/ / mapy.tuzvo.sk/HOFM/Default3.aspx (accessed on 15 March 2021).

38. Ortofotomozaika® GKÚ, NLC, r. 2017. Available online: https://mapy.tuzvo.sk/HOFM/Default3.aspx (accessed on 15 March 2021). 
39. Gabrielsen, P.; Bosch, P. Environmental Indicators: Typology and Use in Reporting; EEA Internal Working Paper: Copenhagen, Denmark, 2003; p. 20.

40. Kanianska, R. Integration of Environmental and Economic Policies and the Method of its Evaluation (In Slovak: Integrácia environmentálnej a ekonomickej politiky a metóda jej hodnotenia). Zivotn. Prostr. 2007, 41, 203-205.

41. Tourism and Its Impact on The environment in the Slovak Republic in 2005 (In Slovak: Cestovný ruch a jeho vplyv na životné prostredie v Slovenskej republike k roku 2005). Available online: https://www.bing.com/newtabredir?url=https $\% 3 \mathrm{~A} \% 2 \mathrm{~F} \%$ 2Fwww.enviroportal.sk\%2Fuploads\%2Fspravy\%2Fturizmus-sektor.pdf (accessed on 29 January 2021).

42. Butler, R.W. The concept of a tourism areas cycle of evolution: Implications for the management of recourses. Canad. Geogr. 1980, 24, 5-14. [CrossRef]

43. Lagiewski, R. The Application of the Talc Model: A Literature Survey. In Aspects of Tourism: The Tourism Area Life Cycle Vol.1 Applications and Modifications, 1st ed.; Butler, R., Ed.; Cromwell Press: Trowbridge, UK, 2006; pp. 27-50.

44. Kurek, W.; Faracik, E.; Mika, M.; Pawlusiński, R.; Pitrus, E.; Ptaszycka-Jackowska, D. Tourism (In Polish: Turystyka), 1st ed.; Wydawnictwo Naukowe PWN: Warszawa, Poland, 2007; pp. 12-49.

45. Gregorová, B.; Neradný, M.; Klaučo, M.; Masný, M.; Balková, N. Tourism and Regional Development (In Slovak: Cestovný Ruch a Regionálny Rozvoj), 1st ed.; UMB: Banská Bystrica, Slovakia, 2015; pp. 6-63.

46. Matlovičová, K.; Matlovič, R. Destination Marketing for Geographers (In Slovak: Destinačný Marketing pre Geografov), 1st ed.; Prešovská univerzita: Prešov, Slovakia, 2017; p. 275.

47. Unique Attraction near Nitra: Seven Meters Underground, There Is a Museum of Socialism (In Slovak: Unikát pri Nitre: Sedem Metrov pod Zemou sa Nachádza Múzeum Socializmu). Available online: https:/ /dromedar.zoznam.sk/cl/1001069/1949205/ Unikat-pri-Nitre--Sedem-metrov-pod-zemou-sa-nachadza-muzeum-socializmu (accessed on 15 January 2021).

48. Museum of Socialism and the Cold War (In Slovak: Múzeum Socializmu a Studenej Vojny). Available online: https://miribord. $\mathrm{com} / \mathrm{sk} /$ aktivity/muzeum/aleksince/muzeum-socializmu-a-studenej-vojny/1623/ (accessed on 30 January 2021).

49. Museum of Socialism and the Cold War (In Slovak: Múzeum Socializmu a Studenej Vojny). Available online: http://www. vypadni.sk/sk/muzeum-socializmu-a-studenej-vojny (accessed on 30 January 2020).

50. Jančura, B.; Beláček, M.; Slámová, M. Visual Aspects and After-effects of Mineral Resources Mining in Landscape (In Slovak: Vizuálne aspekty t’ažby nerastných surovín v krajine). Zivotn. Prostr. 2010, 44, 30-34.

51. Lintnerová, O. Impact of Mining on the Environment (In Slovak: Vplyv t'ažby Nerastných Surovín na Životné Prostredie), 1st ed.; Comenius University: Bratislava, Slovakia, 2002; p. 160.

52. Siepak, M.A. Rock Sanctuary of God's Mercy (In Slovak: Skalné sanktuárium Božieho milosrdenstva), 1st ed.; Wydawnictwo Misericordia: Kraków, Poland, 2017; pp. 103-124.

53. Butkov Cross (In Slovak: Kríž Butkov). Available online: https:/ /www.krizbutkov.sk/ (accessed on 29 January 2021).

54. Basal Environmental Information System of Settlements (In Slovak: Bazálne environmentálne informácie o sídlach Slovenska). Available online: http:/ / www.beiss.sk/ (accessed on 15 January 2021).

55. Ligus, V. Zoning Plan of the Village of Hniezdne (In Slovak: Územný plán obce Hniezdne), 1st ed.; Ateliér Urbeko, S.R.O.: Prešov, Slovakia, 2008; p. 56.

56. Nestville Park. Available online: https:/ /www.nestvillepark.sk/nestville-park/ (accessed on 8 February 2021).

57. Oremusová, D. Geographical Aspects of Regional Development of the Termál Microregion (In Slovak: Geografické Aspekty Regionálneho Rozvoja Mikroregiónu Termál), 1st ed.; UKF: Nitra, Slovakia, 2009; p. 46.

58. Žoncová, M. Evaluation of the diversification of rural landscape in Slovakia after 1989 with a focus on the built-up area of municipalities: A case study of Podhájska municipality. Hung. Geogr. Bull. 2018, 67, 143-158. [CrossRef]

59. The Village of Podhájska. Official Website of the Village (In Slovak: Obec Podhájska. Oficiálna Stránka Obce). Available online: https:/ / www.obecpodhajska.sk/ (accessed on 20 November 2020).

60. Supuka, J.; Štefunková, D. Cultural Landscapes and their Historical Values (In Slovak: Kultúrne krajiny a ich historické hodnoty). Zivotn. Prostr. 2014, 48, 3-8.

61. Forests Slovakia (In Slovak: Lesy Slovenskej Republiky). Available online: https://www.lesy.sk/kontakty/kontaktne-informacie/ (accessed on 20 January 2021).

62. Dadová, J. Load of mining country in Špania Dolina area and possibilities of remediation (In Slovak: Zát'až baníckej krajiny v oblasti Špania Dolina a možnosti remediácie). In Proceedings of the 12nd International Conference Management and Environment, Bratislava, Slovakia, 19-20 November 2012; Rusko, M., Ed.; Strix n.f.: Žilina, Slovakia, 2012.

63. The Village of Špania Dolina (In Slovak: Obec Špania Dolina). Available online: http://www.spaniadolina.sk/en/ (accessed on 20 November 2020).

64. Scarabeo-SK, S.R.O. Economic Development and Social Development Program of the Municipality Čierny Balog $2016-2025$ (In Slovak: Program Hospodárskeho Rozvoja a Sociálneho Rozvoja obce Čierny Balog 2016-2025), 1st ed.; Scarabeo-SK, S.R.O.: Banská Bystrica, Slovakia, 2015; p. 142.

65. Supuka, A. Zoning Plan of the Village of Špania Dolina (In Slovak: Územný Plán obce Špania Dolina), 1st ed.; Landurbia: Banská Bystrica, Slovakia, 2019; p. 96.

66. Čamajová, V. Zoning Plan of the Village of Podhájska (In Slovak: Územný Plán Obce Podhájska), 1st ed.; ABCprint: Žiar nad Hronom, Slovakia, 2017; p. 190.

67. Wall, G. Cycles and Capacity: Incipient Theory or Conceptual Contradiction? Tour. Man. 1982, 3, 188-192. [CrossRef] 
68. Martin, B.S.; Uysal, M. An examination of the Relationship between Carrying Capacity and the Tourism Lifecycle: Management and Policy Implications. J. Environ. Manag. 1990, 31, 327-333. [CrossRef]

69. Keller, C.P. Stages of Peripheral Tourism Development-Canada's North West Territories. Tour. Man. 1987, 8, 20-32. [CrossRef]

70. Snepenger, D.J.; Reiman, S.; Johnson, J.; Snepenger, M. Is Downtown Mainly for Tourists? J. Travel Res. 1998, 36, 5-12. [CrossRef]

71. Wall, G. Cycles and capacity: A contradiction in terms. Ann. Tour. Res. 1983, 10, 268-270. [CrossRef]

72. Stankey, G.H. Integrating wildland recreation research into decision making: Pitfalls and promises. Recreat. Res. Rev. 1981, 9 , 31-37.

73. Getz, D. Capacity to Absorb Tourism: Concepts and Implications for Strategic Planning. Ann. Tour. Res. 1983, 10, 239-262. [CrossRef]

74. Pásková, M. Udržitelný rozvoj cestovního ruchu. Sborník České Geografické Společnosti. 2001, 20, $178-195$.

75. Russo, A.P. A Stakeholders' Approach to Tourism Policy in Bruges. In Tourism Studies in Bruges; WES Research and Consultancy: Bruges, Belgium, 2002; pp. 32-41.

76. Nicu, I.C.; Stoleriu, C.C. Land use changes and dynamics over the last century around churches of Moldavia, Bukovina, Northern Romania-Challenges and future perspectives. Habitat Int. 2019, 88, 101979. [CrossRef]

77. Schulp, C.J.; Levers, C.; Kuemmerle, T.; Tieskens, K.F.; Verburg, P.H. Mapping and modelling past and future land use change in Europe's cultural landscapes. Land Use Policy 2019, 80, 332-344. [CrossRef]

78. Gerard, F.; Petit, S.; Smith, G.; Thomson, A.; Brown, N.; Manchester, S.; Wadsworth, R.; Bugar, G.; Halada, L.; Bezák, P.; et al. Land cover change in Europe between 1950 and 2000 determined employing aerial photography. Prog. Phys. Geogr. 2010, 34, 183-205. [CrossRef]

79. Ollson, E.G.A.; Austrheim, G.; Grenne, S.N. Landscape change patterns in mountains, land use and environmental diversity, Mid-Norway 1960-1993. Landsc. Ecol. 2000, 15, 155-170. [CrossRef]

80. Masný, M.; Zaušková, L'. Multi-temporal analysis of an agricultural landscape transformation and abandonment (L'ubietová, Central Slovakia). Open Geosci. 2015, 7, 888-896. [CrossRef]

81. Špulerová, J.; Dobrovodská, M.; Lieskovský, J.; Bača, A.; Halabuk, A.; Kohút, F.; Mojses, M.; Kenderessy, P.; Piscová, V.; Barančok, P.; et al. Inventory and classifcation of historical structures of the agricultural landscape in Slovakia. Ekologia 2011, 30, 157-170. [CrossRef]

82. Špulerová, J.; Dobrovodská, M.; Izakovičová, Z.; Kenderessy, P.; Petrovič, F.; Štefunková, D. Developing strategy for the protection of traditional agricultural landscapes based on a complex landscape-ecological evaluation (the case study of mountain landscape in Slovakia). Morav. Geogr. Rep. 2013, 21, 15-26.

83. Štefunková, D.; Špulerová, J.; Dobrovodská, M.; Mojses, M.; Petrovič, F. Traditional agricultural landscapes—A model of detailed land use mapping. J. Landsc. Ecol. 2013, 11, 1-21. 